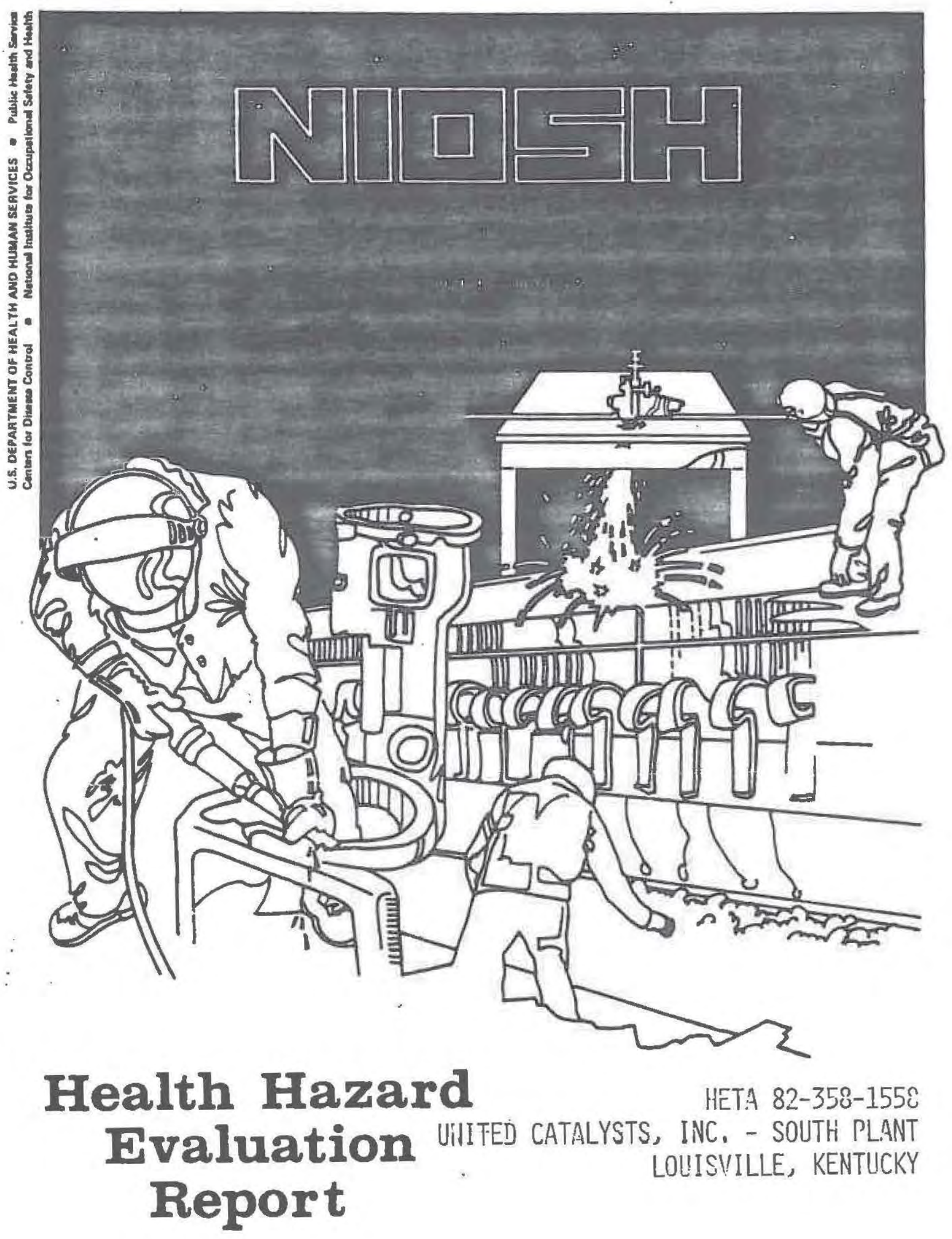


The Hazard Evaluations and Technical Assistance Branch of NIOSH conducts field investigations of possible health hazards in the workplace. These investigations are conducted under the authority of Section $20(a)(6)$ of the Occupational Safety and Health Act of 1970,2 U.S.C. $669(a)(6)$ which authorizes the Secretary of Health and Human Services, following a written request from any employer or authorized representative of employees, to determine whether any substance normally found in the place of employment has potentially toxic effects in such concentrations as used or found.

The Hazard Evaluations and Technical Assistance Branch also provides, upon request, medical, nursing, and industrial hygiene technical and consultative assistance (TA) to Federal, state, and local agencies; labor; industry and other groups or individuals to control occupational health hazards and to prevent related trauma and disease. 
I. SUMMARY

In August and November 1982, the National Institute for Occupational Safety and Health (NIOSH) received a request from the Kentucky Department of Labor to evaluate occupational exposures and related health problems at two catalyst plants operated by United Catalyst Incorporated, Louisville, Kentucky.

In November 1982, NIOSH conducted an initial site visit to the South Plant, subsequently, a follow-up medical and environmental survey were conducted in February and additional environmental surveys in June and July 1983.

Environmental samples were collected for nickel, chromium, chromium VI, copper, cobalt (and other metals), particulates, crystalline silica, sulfuric acid, ammonia, and ionizing radiation.

NIOSH distributed a medical questionnaire to 98 South Plant employees and 235 West Plant employees, reviewed company pulmonary function test results and testing methods, and reviewed company retirement and insurance death records for a possible cancer excess.

Airborne concentrations were: 23 to $680 \mathrm{ug} / \mathrm{m}^{3}$ for nicke 1; 12 to $674 \mathrm{ug} / \mathrm{m}^{3}$ for copper; below the laboratory 1 imit of detection to $37 \mathrm{ug} / \mathrm{m}^{3}$ for chromium; 3 to 7 $\mathrm{ug} / \mathrm{m}^{3}$ for cobalt; below the limit of detection for crystalline silica in personal samples with one area sample value of $0.01 \mathrm{mg} / \mathrm{m}^{3} ; 0.19$ to $0.48 \mathrm{mg} / \mathrm{m}^{3}$ for respirable particulates; 0.8 to $4.2 \mathrm{ug} / \mathrm{m}^{3}$ for chromium VI in four area samples; below the laboratory limit of detection for sulfuric acid; and less than $3 \mathrm{mg} / \mathrm{m}^{3}$ for ammonia. Nickel was the only material in personal samples exceeding current exposure criteria on personal samples. All 33 personal

samples were in excess of the NIOSH recommended standard of $15 \mathrm{ug} / \mathrm{m}^{3}$. The OSHA $\mathrm{PEL}$ for nickel is $1000 \mathrm{ug} / \mathrm{m}^{3}$. Area ionizing radiation readings ranged from $<0.1$ to $>30$ millirem per hour.

Questionnaire data showed that $69 \%$ of the 98 South Plant employees and $72 \%$ of the 235 West Plant employees reported having one or more symptoms. Cough was the symptom reported most of ten at both plants $149 \%$ of South Plant workers and $45 \%$ of West Plant workers). Nasal sores were reported more often by South Plant workers $(35 \%)$ than by West Plant workers $(20 \%)$, and skin rashes were reported more at the West Plant $(39 \%)$ than at the South Plant $(27 \%)$. Smoking status did not appear to affect the prevalence of respiratory symptoms. Symptom prevalence varied according to estimated amount of exposure (high, medium, and low). Almost half of the pulmonary function tests were interpreted in company records as being slightly to severely abnormal. The number and distribution of cancer cases identified do not appear to be unusual.

Major deficiencies were noted in several exposure control programs including employee training and education, engineering controls, respiratory protection, and hou sekeeping.

Based on the results of this investigation, NIOSH investigators have determined that a heal th hazard existed for employees due to nickel exposure. In addition, a potential health hazard existed from exposure to ionizing radiation and chromium VI. Employees were also found to have a high prevalence of work-related symptons. Recommendations to improve employee training, housekeeping, engineering controls, and respiratory protection are made in Section VIII.

KEYWORDS: SIC 2819 (Industrial inorganic chemica1s, chemical catalysts), catalyst manufacturing, nicke1, chromium, chromium VI, ionizing radiation, cough, nasal sores, skin rash. 
Page 2 - Health Hazard Evaluation Determination Report No. HETA 82-358

II. INTRODUCTION

In August and November 1982, the National Institute for Occupational Safety and Health (NIOSH) received a request from the Kentucky Department of Labor to evaluate occupational exposures and employee health at two United Catalysts, Inc. plants (called the South and West Plants) located in Louisville, Kentucky. The request was for an environmental and medical evaluation of the employees at each plant.

This report presents the environmental evaluation for the South Plant only. The medical data from the two plants are combined and presented in both reports.

NIOSH made an initial walk-through survey at each facility on November 2-5, 1982. A follow-up environmental/medical survey was conducted at the South Plant on February 14-18, and March 2, 1983. A second environmental follow-up was conducted on June 30 - July 1 , and July 14, 1983.

Interim report No. 1 was distributed in May 1983. This interim presented the preliminary environmental results and recommendations for improving working conditions at the South Plant. Interim report No. 2, presenting the medical results and recommendations, was distributed in January 1984. Interim report No. 3, distributed in March 1984, presented the environmental findings and additional recommendations from the second follow-up survey.

III. BACKGROUND

History

United Catalysts, Inc. was formed in 1977 by a merger of Catalysts and Chemicals, Inc. and Girdler Chemical, Inc. Girdler Chemical, Inc. (now called the South Plant), began production in the early 1940's as the Girdler Catalyst Division of the Girdler Corporation. Catalysts and Chemicals, Inc. (now known as the West Plant), began operation at its present location in 1957.

\section{Facility Description}

The South Plant has two primary processing areas called Buildings 1 and 11. The South Plant has a union and operates an eight-hour shift. The workforce consists of approximately 135 employees. Job classifications include operators, laborers, warehouse employees, maintenance, and janitors. The operator category includes senior operators, operators, and operator helpers who are responsible for catalyst production. Warehouse personnel and/or laborers monitor screening operations to insure uniformity in the size and shape of the finished products. Maintenance employees are responsible for routine equipment maintenance and emergency repairs. Janitors, laborers and designated maintenance personnel are responsible for general plant housekeeping. 
Page 3 - Health Hazard Evaluation Determination Report No. HETA 82-358

\section{Catalyst Production}

The catalysts manufactured cover a broad range of uses including hydrogen and synthesis gas manufacturing (e.g. carbon monoxide conversion and methanation), gas purification (e.g. conversion of organic sulfur to hydrogen suifide), hydrogenation (e.g. hydrogenation of fats and oils), dehydrogenation (e.g. styrene manufacturing), oxidation (e.g. production of sulfuric acid), synthesis and dissociation (e.g. methanol synthesis), acid catalysts (e.g. alkylation). Custom catalysts made to the specification of the client are also produced.

A finished catalyst will typically consist of the reactive component such as nickel, chromic oxide, and phosphoric acid, or a combination such as iron oxide/potassium carbonate, on a carrier such as aluminum oxide, and silicon dioxide. Some catalysts, however, have no carrier, consisting only of the reactive or functional component. The percentage of the chemicals that constitute the reactive component cover a broad range. Nickel, for example, varies from less than $1 \%$ in some mixed metal catalysts, to in excess of $60 \%$ in some catalysts in which it is the sole reactive component.

Specific catalyst carriers are formulated to provide various chemical and physical properties. Depending on raw materials used, surface areas can range from below $0.1 \mathrm{~m}^{2}$ per gram to more than $200 \mathrm{~m}^{2}$ per gram. The carriers are available in various shapes, including spheres, cylinders, rings, tablets, gears, irregular shaped granules and fluid-bed spherical particles.

Catalyst manufacturing is based primarily on batch production which involves mixing raw materials and then forming the raw materials into the desired shape. Subsequently, the material is calcined to cure it and then screened to insure uniform size and shape for the finished product. The actual catalyst production can be relatively simple or quite complex, depending on the specific catalyst involved and whether it is produced using a dry (generally less complex) or a wet system.

One of the simpler catalyst production processes involves mixing the raw materials (phosphoric acid and diatomaceous earth) while simultaneously forming the mix into spheres. Subsequently, the material is sent through a calciner to be dried and cured. After screening, the material is ready for shipment. Conversely, a more complex process involves initially dissolving nickel metal into a solution of aqua ammonia and carbon dioxide to form nickel amine carbonate. Subsequently, a carrier $\left(\mathrm{SiO}_{2}\right)$ is added and the nickel amine carbonate is precipitated onto the carrier. The material is then filtered to reduce the moisture content, and the resulting slurry is processed through a spray dryer to remove more of the moisture and 
Page 4 - Health Hazard Evaluation Determination Report No. HETA 82-358

separate out improper sized particles. Next, the material is calcined, which converts it to nickel oxide by removing ammonia and carbon dioxide. Next, then sent to a reduction furnace where it is converted to nickel metal, then stabilized using soya oil, and subsequently formed into flakes. The material is then ready for shipment. The time required to produce a catalyst varies from two to 24 hours for most catalysts. For those which require repeated processing steps such as washing or dipping, additional time is required.

The wide range in catalyst function, and modification which can be made to a particular catalyst series, result in a large number of catalysts that can, and have been produced at each plant. There are, however, a much smalier number of catalysts that constitute most of the day to day production. Some catalysts are run almost every day, while others will be produced sporadically. Approximately half of the catalysts produced at the South Plant contain nickel in the reactive component. The majority of the remaining routinely produced catalysts contain copper, zinc, iron, or cobalt in the reactive component.

Screening at the South Plant is perfomed at various locations, as opposed to the West Plant which has a central screening area.

The South Plant, at one time, produced a catalyst that used depleted uranium as a raw material. Production of this catalyst ceased a few years ago but a similiar catalyst was scheduled to start again in late 1983 or 1984.

\section{Raw Materials}

The list of raw materials used at these facilities is quite extensive. The primary chemicals include metals (nickel, copper, aluminum, zinc, chromium, platinum, palladium, iron, molybdenum, cobalt, vanadium, bismuth) in the form of a metal wire or brick, metal powder, metal oxide, or metal nitrate; acids (phosphoric, nitric, and sulfuric); and other materials including diatomaceous earth, attapulgite clay, aluminum oxide, sodium hydroxide, sodium bichromate, ammounium zirconiuim carbonate, potassium carbonate, cerium carbonate, aqua amonia, hydrogen, carbon dioxide, soya oil, air, and water.

\section{Processing Equipment}

Major types of processing equipment used at these facilities include:

1. Dryers - to reduce the moisture content of a material.

2. Calciners - to reduce moisture content, attain the appropriate particle size, and/or to change the chemical nature of a material (e.g. remove nitrates from a metal nitrate solution to form a metal oxide). 
Page 5 - Health Hazard Evaluation Determination Report No. HETA 82-358

3. High temperature furnaces - used to heat treat and subsequently strengthen certain types of formed catalyst carriers (e.g. aluminum oxide rings).

4. Spray dryers - used to produce a high-moisture solid out of a liquid slurry and subsequently separate out improperly sized particles.

5. Filters - used to remove the solid component of a solution.

6. Filter presses - used to separate components and to remove impurities from a solution during washing operations.

7. Reduction furnaces - used to reduce nickel oxide using hydrogen.

8. Stabilization units - used to stabilize elemental nickel using either an oil process (soya oil) or dry stabilization with a mixture of oxygen and carbon dioxide.

9. Strip tanks - in which steam heat is used to remove ammonia and carbon dioxide from a metal amine carbonate solution forming a metal oxide.

10. Precipitation tanks - in which the reactive component of a catalyst is precipitated onto a carrier.

11. Decant tanks - in which heavier materials are allowed to settle and subsequently, the liquid upper portion is removed.

12. Grinding mills - used to reduce the particle size.

13. Mixers - used to combine materials.

14. Drum elevators - used to raise and empty drums of materials.

15. Forming machines (which include tablet machines, ring machines, extruders, and ball wheels) - used to produce various sizes and shapes of the finished catalyst material.

16. Reactors - in which metal raw materials are dissolved into solution.

IV. EVALUATION DESIGN AND METHODS

A. Environmental

The environmental investigation consisted of an evaluation of the West Plant's exposure control programs and collection of environmental samples for various chemical and physical agents. 
Page 6 - Health Hazard Evaluation Determination Report No. HETA 82-358

Environmental data collected by management was reviewed prior to collection of environmental samples. The data was helpful in estimating the magnitude of exposure for some jobs. It was limited however, in that exposures had been evaluated for total and/or respirable airborne material only rather than for specific chemicals (i.e. nickel).

Airborne monitoring was conducted to evaluate employee exposures to airborne concentrations of particulates, metals, hexavalent chromium (chromium VI), crystalline silica, ammonia, sulfuric acid, and aliphatic and aromatic amines. In addition, a sample of insulation was analyzed for asbestos. Additionally, direct-reading samples were collected as a spot check for vapors and/or gases and ionizing radiation. Bulk material and settled dust samples were collected to evaluate inorganic metals and crystalline silica content.

Respirable Particulates

Respirable dust samples were collected on polyvinyl chloride (PVC) filters contained in two-piece plastic cassettes attached via flexible tubing to a battery-operated pump calibrated at 1.7 liters per minute $(1 \mathrm{pm})$. The filter and cassette were loaded into 10 millimeter nylon cyclones. The samples were analyzed by weighing the collected dust plus the filter on an electrobalance and subtracting the previously determined tare weights of the filters. Respirable samples were analyzed for crystalline silica content.

High-volume area airborne respirable particulate samples were collected on PYC filters (in 2 piece plastic cassettes) loaded into a 1/2-inch stainless steel cyclone attached via flexible tubing to an electric vacuum pump. A critical orifice located in the tubing controlled the flow rate at approximately $91 \mathrm{pm}$. High-volume and personal respirable samples were analyzed for percent crystalline silica using $X$-ray diffraction according to NIOSH Method No. P\&CAM 259 (modified). 1

Metals

Metals samples were collected on mixed cellulose ester membrane filters attached via flexible tubing to battery-operated pumps calibrated at $1.5 \mathrm{lpm}$. Some of these samples were analyzed for specific metals (chromium and nickel) using atomic absorption according to NIOSH Method No. P\&CAM 173.1 Other metals samples were analyzed for 28 metals using inductively coupled plasma-atomic emission spectroscopy (ICP-AES). 
Page 7 - Health Hazard Evaluation Determination Report No. HETA 82-358

Chromium VI

Chromium VI samples were collected on PVC filters attached via flexible tubing to battery-operated pumps calibrated at $27 \mathrm{pm}$. These samples were analyzed by colorimetric spectrophotometry according to NIOSH Method No. P\&CAM 319.2

\section{Amines}

Samples for airborne amines were collected on citric acid-coated silica gel tubes attached via flexible tubing to battery-operated pumps calibrated at $0.17 \mathrm{pm}$. The samples were then screened qualitatively for aliphatic and/or aromatic amines since only one type (aliphatic or aromatic) could be evaluated on individual samples. Aliphatic amines were evaluated according to NIOSH Method No. P\&CAM 276.3 Aromatic amines were analyzed according to NIOSH Me thod No. P\&CAM 168.1

\section{Ammonia}

Samples for airborne ammonia were collected on sulfuric acid-treated silica gel tubes preceded by a mixed cellulose ester membrane filter. The samples were attached via flexible tubing to battery operated pumps calibrated at approximately $0.051 \mathrm{pm}$. These samples were analyzed using a colorimetric automated phenate method. Grab samples for ammonia were collected using NIOSH certified directreading detector tubes with a corresponding detector tube pump. The samples were evaluated visually in the field.

\section{Sulfuric Acid}

Samples for airborne sulfuric acid were collected on sllica gel tubes attached via flexible tubing to battery-operated pumps calibrated at $0.11 \mathrm{pm}$. The samples were analyzed using ion chromatography according to NIOSH Method No. P\&CAM 339.4

\section{Bulk Samples}

The insulation sample was collected in a glass sample via, and analyzed for the percent and type of asbestos present, utilizing polarized light microscopy and dispersion staining techniques.

Material bulk samples were collected in glass sample vials and analyzed for percent crystalline silica utilizing X-ray diffraction. Two milligram portions of each material bulk sample were weighed onto PVC filters in duplicate. The samples were then analyzed according to NIOSH Method No. P\&CAM 259 (modified). 1 
Page 8 - Health Hazard Evaluation Determination Report No. HETA 82-358

Settled dust samples were collected in glass sample vials and subsequently analyzed for the percent (by weight) of various metals. Replicate aliquots of each sample were weighed and digested in acids. The resulting solutions were analyzed by ICP-AES.

Ionizing Radiation

Area radiation measurements were obtained using a Mini Con-Rad portable survey meter (Model 3032) during the first follow-up survey. Readings were obtained for the total exposure rate from alpha, beta, and gamma radiation. For the second follow-up survey, beta/gamma and alpha radiation were evaluated separateiy using a Ludlum Measurements, Inc., Model 3 Survey Meter; and Ludlum Measurements, Inc., Model 12 Count Ratemeter, respectively.

Sampling and analytical techniques for all materials evaluated are listed in Table I.

B. Medical

1. Questionnaires

A questionnaire seeking information on demographic characteristics; smoking, work, and medical histories; and current health problems was distributed to 98 employees at the South Plant and 235 at the West Plant. The purpose was to determine if employees at United Catalyst exhibit symptoms associated with potential exposures at the plant. Questionnaires were administered to employees in groups ranging in size from 15 to 25. (This procedure allowed the NIOSH investigator to explain the purpose of the survey and to answer specific questions about the survey and the questionnaire.) For analysis of the questionnaire data, employees were divided into high, medium, and low exposure groups using the environmental total airborne metals concentrations collected during the first follow-up survey, and for those jobs not monitored, the NIOSH industrial hygienist's estimates of relative exposure.

\section{Record Review}

To evaluate the possibility of an excess cancer rate at United Catalyst, a union-supplied 7 ist of 43 occurrences of illnesses and/or deaths among employees was reviewed. This Tist was prepared by several sentor plant employees. In addition, the company's retirement benefit plan and death records dating back to 1977 were reviewed. Finally, company insurance carriers were contacted concerning their death records on nasal and lung cancer, cancer types which are associated with exposure to nickel and hexavalent chromium. 
Page 9 - Health Hazard Evaluation Determination Report No. HETA 82 -358

The company's pulmonary function test (PFT) results, the testing methods, and criteria for interpretation were reviewed. These records contain one set of PFT's for each employee. The company began the testing in 1982, and reportedly plans. to continue the program, along with additional medical surveillance, on an annual basis.

V. EVALUATION CRITERIA

A. Environmental Evaluation

As a guide to the evaluation of the hazards posed by workplace exposures, NIOSH field staff employ environmental evaluation criteria for assessment of a number of chemical and physical agents. These criteria are intended to suggest levels of exposure to which most workers may be exposed up to 10 hours per day, 40 hours per week for a working lifetime without experiencing adverse heal th effects. It is, however, important to note that not a 11 workers will be protected from adverse health effects if their exposures are maintained below these levels. A small percentage may experience adverse health effects because of individual susceptibility, a pre-existing medical condition, and/or a hypersensitivity (allergy).

In addition, some hazardous substances may act in combination with other workplace exposures, the general environment, or with medications or personal habits of the worker to produce health effects even if the occupational exposures are controlled at the level set by the evaluation criterion. These combined effects are often not considered in the evaluation criteria. Also, some substances are absorbed by direct contact with the skin and mucous membranes, and thus potentially increase the overall exposure. Finally, evaluation criteria may change over the years as new information on the toxic effects of an agent become available.

The primary sources of environmental evaluation criteria for the workplace are: (1) NIOSH Criteria Documents and recommendations, (2) the American Conference of Governmental Industrial Hygienist (ACGIH) Threshold Limit Values (TLV's), and (3) the U.S. Department of Labor (OSHA) occupational health standards.5-8 often, the NIOSH recommendations and ACGIH TLV's are lower than the corresponding OSHA standards. Both NIOSH recommendations and ACGIH TLV's usually are based on more recent information than are the OSHA standards. The OSHA standards also may be required to take into account the feasibility of controlling exposures in various industries where the agents are used; the NIOSH-recommended standards, by contrast, are based primarily on concerns relating to the prevention of occupational disease. In evaluating the exposure levels and the recommendations for reducing these levels found in this report, it should be noted that industry is legally required to meet only those levels specified by an OSHA standard. 
Page 10 - Health Hazard Evaluation Determination Report No. HETA 82-358

A time-weighted average (TWA) exposure refers to the average airborne concentration of a substance during a normal 8- to 10-hour workday. Some substances have recommended short-term exposure limits or ceiling values which are intended to supplement the TWA where there are recognized toxic effects from high short-term exposures.

Environmental criteria and associated health effects for materials evaluated at the South Plant are included in Table II.

Following is a discussion of the principal materials evaluated at the South Plant:

B. Chromium

Chromium compounds may exist in the bivalent $(+2)$, trivalent $(+3)$ or hexavalent $(+6)$ states. Exposure to chromium compounds has been associated with dermatitis and the development of pulmonary sensitization. In general, bivalent and trivalent compounds are considered to be of a low order of toxicity. 7,9

Hexavalent chromium compounds have been implicated in a number of health problems including skin ulceration, ulcerated nasal mucosal, perforated nasal septum, rhinitis, nosebleed, perforated eardrums, kidney damage, pulmonary congestion and edema, epigastric pain, erosion and discoloration of the teeth, and dermatitis. In addition, some hexavalent chromium compounds have been associated with an increased rate of lung cancer. 10

Noncarcinogenic chromium $(+6)$ compounds include the monochromates and bichromates of hydrogen, lithium, sodium, potassium, rubidium, cesium, and ammonium, and chromium $(+6)$ oxide (chromic acid anbydride). All other chromium $(+6)$ compounds are considered carcinogenic. 10

The OSHA Permissible Exposure LImit (PEL) for chromium compounds is $0.5 \mathrm{mg} / \mathrm{m}^{3}$ for soluble chromic and chromous salts as $\mathrm{Cr}$, and 1.0 $\mathrm{mg} / \mathrm{m}^{3}$ for chromium metal and insoluble salts, with a ceiling value of $0.1 \mathrm{mg} / \mathrm{m}^{3}$ for chromic acid and chromates. 8 The ACGIH TLV is $0.50 \mathrm{mg} / \mathrm{m}^{3}$ for chromium metal, and chromium +2 and +3 compounds. The TLY for +6 chromium compounds is $0.05 \mathrm{mg} / \mathrm{m}^{3}$, with certain water insoluble compounds being considered as human carcinogens.6-7 The NIOSH recommended standard is $0.025 \mathrm{mg} / \mathrm{m}^{3}$ for noncarcinogenic, and $0.001 \mathrm{mg} / \mathrm{m}^{3}$ for carcinogenic chromium (+6) compounds. 10 
Page 11 - Health Hazard Evaluation Determination Report No. HETA 82-358

C. Nickel

Nickel is a malleable and ductile, ferromagnetic metallic element which is resistant to corrosion in many acids, salts and alkalis, water, and gases. In addition to catalysts, nickel is used in alloys such as stainless steel. It is also used in electroplating, production of magnetic tapes, coins, batteries and paints.11

Exposure to nickel and its compounds has been associated with many health effects including allergic reactions, irritation of the skin and mucous membranes, and an increased incidence of various types of cancer.11-12 Nickel and its compounds are among the most common causes of allergic dermatitis. Nickel is also associated with irritation of the conjunctivia of the eye and mucous membranes of the upper respiratory system. Perforation of the nasal septum is another reported symptom. $9-11$

Workers in the nickel refinery industry were found to have an increased incidence of lung and nasal cancer.11-12 The exact nickel compounds responsible for the increased cancer risk were not definitely proven, but nickel subsulfide, nickel oxide, nickel chloride, and nickel sulfate were among the suspected materials.12

In establishing its criterion for exposure to nickel, ACGIH distinguished between nickel metal and insoluble nickel compounds, and soluble nickel compounds. Additionally, nickel sulfide roasting dusts and fume were designated as being associated with an increased risks of respiratory cancer. 7

NIOSH, however, defines "nickel" as elemental nickel and includes all nickel materials except organonickel compounds. In the criteria document for occupational exposure to inorganic nickel, NIOSH states: "There is overwhelming evidence that nickel refinery workers have had an excess of deaths from cancer of the respiratory organs. Evaluation of this evidence has led NIOSH to conclude that many of these cancers were nicke1-induced, and that inorganic nickel should be regarded as a carcinogen." The NIOSH recommended standard for nickel is $15 \mathrm{ug} / \mathrm{m}^{3} .12$

D. Copper

Copper dusts or mists can affect the body through inhalation, ingestion, or direct contact. 5

Short-term exposures to powdered copper or dust and mists of copper salts are associated with cold-like symptoms including sensation of chills and head stuffiness. If copper particulates enter the eyes they may cause irritation, discoloration, and damage.5 
Page 12 - Health Hazard Evaluation Determination Report No. HETA 82-358

Inhalation of dusts and mists of copper and copper salts may cause mucous mambrane irritation and may also cause ulceration with perforation of the nasal septum. 5,13 other symptoms reported to be associated with metallic copper exposure are keratinization of the hands and soles of the feet, metallic taste, nausea, metal fume fever and discoloration of skin and hair. The OSHA PEL and ACGIH TLV for copper dust are $1000 \mathrm{ug} / \mathrm{m}^{3}$. NIOSH currently has no recommended standard for copper.

E. Ionizing Radiation

Radiation is energy which is emitted, transmitted, or absorbed in wave, or energetic particle form. One can think of the wave as the disturbance that transfers energy progressively from one point to another point in a medium. The electromagnetic spectrum consists of a continuum of radiation ranging from below radio frequencies to above ionizing, including microwave, infrared, visible, and ul traviolet radiation.

Ionizing radiation has always been a part of the natural environment, and since the discovery of $X$-rays and radioactivity, it has become a part of the industrial environment of many workers. Radioactive material spontaneously changes to a lower energy state, emitting particles and/or rays, such as alpha particles, beta particles, and gamma rays.

Alpha particles interact readily with matter to produce ions. These particles have a high energy but are stopped by a few centimeters of air or by the intact skin. These particles are not an external hazard but if alpha emitting elements are taken into the body, serious internal exposures may result.

in

Beta particles interact much less readily with matter than alpha particles and will thus travel further in air or tissue. Exposure to external sources of beta particles is potentially hazardous, but internal exposure is more hazardous. Gamma rays are primarily on external hazard because they can travel great distances in air or tissue. To stop gamma rays, several inches of a dense shielding material (i.e. lead) would be required.

The early experience of radiation workers, including the exposure of radium dial-painters, and data from research projects provide clear evidence that high levels of ionizing radiation definitely create somatic damage and may induce genetic damage. The somatic effects include radiodermatitis, epilation, acute radiation syndrome, cancer, leukemia, cataracts, sterility and life span shortening. 9 
Page 13 - Health Hazard Evaluation Determination Report No. HETA 82-358

The current Nuclear Regulatory Commission standard for unrestricted areas is 2 millirems (mR) in any one hour. The OSHA standard is based on quarterly measurements. For whole body exposures in restricted areas the OSHA limit is $11 / 4$ Rem per quarter calendar year.

VI. RESULTS

A. Environmental

1. Environmental Sampling, First follow-Up Survey

Metals

Table III presents the results of airborne sampling for five metals most likely to cause health effects. Airborne concentrations of nickel ranged from 23 to 680 micrograms per cubic meter of air $\left(\mathrm{ug} / \mathrm{m}^{3}\right)$. All 33 personal sample results are above the NIOSH recommended standard of $15 \mathrm{ug} / \mathrm{m}^{3}$. Thirteen were more than six times, and two were more than 40 times, the NIOSH recommendation. One sample result was approximately $70 \%$ of the OSHA PEL and ACGIH TLV of $1000 \mathrm{ug} / \mathrm{m}^{3}$.

Airborne concentrations of copper ranged from 12 to $674 \mathrm{ug} / \mathrm{m}^{3}$. One of the 12 sample results $\left(674 \mathrm{ug} / \mathrm{m}^{3}\right)$ was $67 \%$ the OSHA PEL and ACGIH TLV of $1000 \mathrm{ug} / \mathrm{m}^{3}$. Airborne concentrations of lead ranged from below the laboratory 7 imit of detection to $7 \mathrm{ug} / \mathrm{m}^{3}$. A17 12 sample results were less than $15 \%$ of the lowest current environmental criterion, the OSHA standard of $50 \mathrm{ug} / \mathrm{m}^{3}$. Concentrations of airborne cobalt ranged from 3 to $7 \mathrm{ug} / \mathrm{m}^{3}$. All sample results were below the current criteria of $100 \mathrm{ug} / \mathrm{m}^{3}$ (OSHA and ACGIH as an 8-hour TWA).

Airborne concentrations of total chromium ranged from below the laboratory limit of detection to $37 \mathrm{ug} / \mathrm{m}^{3}$. All 33 sample results were less than $10 \%$ of the lowest current criterion for total chromium of $500 \mathrm{ug} / \mathrm{m}^{3}$ (ACGIH).

Respirable Particulate and Crystalline Silica

Table IV presents the results of personal and area sampling for respirable particulates. Airborne concentrations ranged from 0.19 to $0.48 \mathrm{mg} / \mathrm{m}^{3}$. All sample results were less than $10 \%$ of the current criterion of $5 \mathrm{mg} / \mathrm{m}^{3}$ (OSHA and ACGIH). 
Page 14 - Health Hazard Evaluation Determination Report No. HETA 82-358

Table IV also presents the results of sampling for crystalline silica. Two polymorphs of crystalline silica (quartz and cristobalite) were evaluated in each sample. Neither material was detected in any of four personal samples. Quartz was detected in one high-volume area sample at a concentration of $0.01 \mathrm{mg} / \mathrm{m}^{3}$. This is approximately $20 \%$ of the 1 owest current criterion, $0.05 \mathrm{mg} / \mathrm{m}^{3}$ (NIOSH). Of the bulk material samples evaluated for crystalline silica, one contained 1.9 percent quartz. This was a raw material used in some of the nickel catalysts.

Chromium VI

Table $V$ presents the results of four area samples for chromium VI. Airborne concentrations ranged from 0.8 to $4.2 \mathrm{ug} / \mathrm{m}^{3}$. Three of the sample results were above the NIOSH criterion for carcinogenic chromium VI materials of $1 \mathrm{ug} / \mathrm{m}^{3}$. All sample results were below all other criteria.

\section{Sulfuric Acid}

Table VI presents the results of three personal samples for airborne sulfuric acid in Building I. All concentrations were below the laboratory limit of detection ( $4 \mathrm{ug} / \mathrm{sample}$ ).

Ammonia

Table VII presents the results of three area and two personal samples for airborne ammonia. The highest values were 8.99 $\mathrm{mg} / \mathrm{m}^{3}$ for area samples and 2.89 for personal samples. A11 area sample results were less than $50 \%$ of the ACGIH TLV of 18 $\mathrm{mg} / \mathrm{m}^{3}$, and the personal sample results were less than $20 \%$ of the TLV, which is the lowest full shift criterion.

Table VIII presents the results of sampling for airborne ammonia using direct-reading gas detector tubes. Airborne concentrations ranged from a trace (not sufficient for quantitation) to 42 parts per million (ppm). The highest concentrations were obtained on the third floor near the $\mathrm{H}-230$ amine prep tank in Building 2. All values are below the NIOSH recommended level of $50 \mathrm{ppm}$ which is a ceiling value for a 5-minute period. NIOSH previously conducted a voluntary gas detector tube certification program. Direct-reading gas detector tubes were certified to an accuracy of $+35 \%$ at one-half the test gas concentration and $\pm 25 \%$ at 1,2 , and 5 times the test gas concentration. The tēst gas concentration usually corresponded to the OSHA PEL.8,14,15 
Page 15 - Health Hazard Evaluation Determination Report No. HETA 82-358

At the time of the follow-up surveys, the certification program was in effect, subsequently, in September 1983, it was terminated. 16

Bulk Dust

Table IX presents the results of analyses for the five biologically most important metals in settled dust samples. Nickel was the most abundant metal; approximately $38 \%$ in two samples collected on the second floor in Building 2, and greater than $25 \%$ of a sample from the third floor of Building 2 at the $\mathrm{H}-230$ Prep Area. This is probably one reason that every employee monitored for metals exposure (Table III) had a nickel concentration in excess of the NIOSH recommended standard. The only other metal found to be in excess of $1 \%$ was cobalt. It constituted approximately $4 \%$ of dust collected from the top (above the mezzanine) of Building 1. These results indicate that airborne concentrations of these metals may be increased as a result of employee activities that disturb general dust buildups throughout the plant. While this is obvious for nickel, it could also occur for other metals which have relatively low exposure limits (lead, chromium VI).

Ionizing Radiation

Table $X$ presents the resuits of sampling for total ionizing radiation (which includes alpha, beta, and gamma). The main area of concern was in Building 1 on and above the Mezzanine where depleted uranium had been used previously. Other areas (Building 2) were monitored for comparison purposes. Readings in Building 2 were all below the NRC limit for unrestricted areas of 2 millirem in any hour. The highest readings were obtained on and above the mezzanine in Building 1.

Most of these readings were still relatively low and would not result in personal exposures above the criterion unless employees remained in the area for extended periods. There was one spot, however, where the readings obtained were much higher than the criterion. The highest readings were obtained when a torn piece of covering on the spray dryer was pulled out and a reading obtained of the material behind the cover. The reading listed in Table IX are all surface readings obtained within a few inches of the surface indicated. Thus, these readings are not directiy comparable to the 2 millirem criterion. However, these readings indicate a potential for exposures above the criterion. 
Page 16 - Health Hazard Evaluation Determination Report No. HETA 82-358

\section{Insulation Sample}

The sample of insulation material collected from the $P$ and $S$ Burner stack (3rd floor, Building 2) did not contain any asbestos material.

\section{Amine Screening Samples}

No peaks other than those associated with the solvent were detected in samples for aliphatic amines. In the aromatic amine samples, one peak was found that eluted with the solvent used for analysis. The peak is thought to be due to the ammonia which was present in the areas where the samples were collected (1st and 3rd floor, Bullding 2). Laboratory checks of ammonia's retention time revealed that it matched that of the unknown peak under the conditions of analysis.

\section{Environmental Sampling, Second Follow-up Survey}

During the second follow-up survey, the NIOSH industrial hygiene team concentrated on a further evaluation of the company exposure reduction programs, including respiratory protection, engineering controls, and housekeeping. Additional1y, the $41 / 61$ process area on the mezzanine of Building 1 was reevaluated for ionizing radiation.

Table XI presents the results of sampling for ionizing radiation on July 14, 1983. Measurements obtained during the first follow-up survey had indicated a potential hazard due to the combined effects of alpha, beta, and gamma radiation. The ionizing radiation meters used on the second follow-up survey, enabled the NIOSH industrial hygienist to assess the potential hazard from alpha and beta/gamma radiation separately.

The majority of measurement in Table XI are surface measurements. Alpha radiation values did not exceed the background levels obtained in the office. Beta/gamma readings ranged from $0.01 \mathrm{milli}$ rem per hour $(\mathrm{mR} / \mathrm{hr})$ to $8 \mathrm{mR} / \mathrm{hr}$. The highest readings were obtained on a platform located at the 41/61 spray dryer. A few readings were taken at waist height, 2-3 feet from the spray dryer door. These readings ranged from 0.7 to $3.5 \mathrm{mR} / \mathrm{hr}$. Readings taken farther away from the spray dryer door showed less radiation.

The readings obtained during this survey are similiar to the readings obtained during the March survey (Table IX) and indicate a potential hazard to employees who work near or on the spray dryer platform for long periods. There is also a 
Page 17 - Health Hazard Evaluation Determination Report No. HETA 82-358

potential hazard due to ingestion of radiation-laden material. There would probably not be a significant hazard for employees who are only passing through the area. There could be a serious hazard, however, to employees involved in maintenance/ cleaning activities on the spray dryer.

3. General Observations

Problems were noted for the company's exposure control programs including respiratory protection, engineering controls and housekeeping.

The respiratory protection program needs to be improved as evidenced by the fact that employees were not always aware of the correct respirator they were supposed to use. The employee loading the pulvacron was observed using a disposable respirator until a supervisor told him to wear a different (full facepiece) type. In addition, several of the employees at this facility had beards, which are known to compromise the respirators effectiveness.

Other deficiencies in the respiratory protection program included storage, maintenance, improper use, and enforcement of respiratory use areas. Maintenance problems were highlighted by the fact that a self-contained breathing apparatus (SCBA) was not fully charged. This could have serious consequences for an employee who needed to use the SCBA to enter a hazardous environment. In general, respirators other than single use (disposable) were poorly maintained. Respirator use is generally not welcomed by employees. Dirty respirators add to the unpleasantness of wearing respiratory protection.

While visible airborne dust was not excessive during normal operations, there were certain operations which were observed to create a lot of airborne material. These included loading the pulvacron in Building 2. This involved putting a barrel of powdered material on to a small loader. Each time the barrel hit one end of the barrel container, small clouds of dust were generated.

Another source of airborne particulate was the open barrels used for transferring material around the plant and for temporary storage. Clouds of particulates were visible coming out of the barrels for several seconds after the barrels were moved or emptied. 
Page 18 - Health Hazard Evaluation Determination Report No. HETA 82-358

The engineering control program needs significant improvements in order to be effective. Engineering controls observed at the plant were poorly maintained. There was no routine monitoring (i.e. face velocity, duct velocity measurements) of the engineering controls in place. Some ventilation hoods and/or ducts had holes or corroded areas. Any hole in a duct or hood reduces its effectiveness. Specific problems were noted at the X-215 stabilization/reduction furnace where a short hose running from the furnace to a screener was not attached to the screener lip. Thin plastic sheets had been placed on top of the screener in an apparent attempt to reduce emissions.

There is need for additional engineering controls at various locations in both Buildings 1 and 2 . There are a number of drum filling stations in both buildings. This involves filling a drum via material exhaust ports such as a short (6" diameter) flexible hose. For example, X-215 stabilizer/reduction furnace, had three drum being filled simultaneously (one for product, two for odd sized materials). None of the three drum filling stations were covered or exhausted. Visible dust was seen rising out of each barrel during drum filling. Some of the other drum filling stations had covers and some were equipped with a gasket located inside the cover, such as the one located next to the supervisor's office in Building 2. Some drum filling stations had covers but no gaskets, such as those located at the exit end of Rotary Calciner No. 4 on the 1st floor of Building 2 .

Other needed engineering controls include a fluid level meter for the stainless steel tank located on the first floor of Building 2. Presently, when the tank is filled, an employee stands above it (the employee is actually on the second floor) and uses a wire running through the grid floor to open the tank lid so as to monitor the level of material in the tank. When the lid is raised, ammonia vapor and steam rise from the tank and engulf anyone standing above it.

Housekeeping was deficient in most areas. In particular, the floors of the locker/bathroom and lunchroom areas were not clean. The biggest problem with overall houskeeping is the amount of material escaping from processing equipment and eventually ending up on the floor. Subsequently, employee and vehicular traffic spread the material throughout the plant. One example of this is the new $6-64$ area as evidenced by the spread of red colored material into adjacent processing areas. Materials that escape during processing can present problems other than increasing employees exposure to hazardous chemicals. According to some employees, one such problem occurred at the new G-64 area. Employees stated that one of the raw materials (potassium carbonate) was hydrophilic and became very slippery on humid days making it very difficult to walk ir. the area. 
Page 19 - Health Hazard Evaluation Determination Report No. HETA 82-358

A number of potential health and/or safety problems were observed. These included an unsanitary emergency eye wash station on the third floor of Building 2. One of two water nozzle covers was off and both nozzles were very dirty. Other problems included an emergency eye wash/shower station located on the mezzanine of Building 1 , which was almost inaccessible because a portable set of steps was blocking access to it. Another potential hazard is that some of the Targe liquid storage tanks located on the first floor in Building 1 are not properly labeled. In addition, there was no apparent set procedure as to what actions to take if a tank did rupture.

Welding operations were observed on several occasions. Welding jobs were not partioned off and no welding screens were used. Potential hazards from welding include severe eye irritation, and skin burns from sparks and hot bits of metal.

The NIOSH investigators noted that some old processing equipment that had previousiy been described as "no longer used" was being used during the second follow-up survey. This equipment was reportedly pressed into service due to an unexpected need to reprocess a large amount of G-64 catalyst. A concern exists because this equipment and some other nonactive processing equipment was not well maintained. A hood located on the mezzanine in Building 1, for example, was corroded, had holes in some locations, and had duct tape holding one corner together. Should this equipment be used in the future, it would probably emit a lot of airborne material.

There were some noticeable improvements in conditions during the second follow-up survey. In particular, the small bathroom in Building 2 had been cleaned and painted. This increases the usefullness of the bathroom for personal hygiene. Another improvement was noted at the old carmen bagger in Building 2. During the initial follow-up survey, employees had expressed concern about the structural integrity of the bagger. Subsequently, the Kentucky Department of Labor evaluated the bagger and found it to be structurally sound but in need of a major cleaning effort. The unit had been sandblasted and painted prior to the second follow-up visit. Another noted improvement concerned the tables in the lunchroom. They had been refurbished and were much cleaner than at the time of the initial follow-up survey. However, as noted previously the remainder of the lunch room was not clean. In addition to these improvements, the company had some good techniques and or work practices. Employees are provided with workclothes (including safety shoes) and given time to shower at the end of the shift. These are good preventative measures to help insure that employees do not transport hazardous chemicals (nickel, 
Page 20 - Health Hazard Evaluation Determination Report No. HETA 82-358

chromium, etc.) home, where family members could be exposed. Currently employees are given the opportunity to shower, but some employees choose not to shower. It would be more effective if employees had to enter and leave the processing areas by going through the shower area.

B. Medical

1. Questionnaire Analysis

a. Demographic

The 98 South Plant employees were similar to the 235 West Plant employees in age, proportion of males and females, and current smoking status (Table XIV).

The proportion of employees having one or more symptoms at the South Plant (70\%) was similar to that at the West Plant (72\%) (Table XV). The symptom reported most often at both plants was cough. Nasal sores were reported more of ten at the South Plant (35\%) than at the West Plant (20\%), and skin rashes were reported more often at the West Plant (39\%) than at the South Plant (27\%). Other symptoms were reported by comparable proportions of employees at the two plants.

The rank order of areas of the body affected by skin rash was the same at both plants (Table XVI). The area most often reported was the hands. The area least often reported was the feet. At the South Plant, affected employees reported a higher prevalence of rash at each area than West Plant employees. The differences for hands, face and neck, and arms were statistically significant. This could happen because an employee could list more than one location. Therefore, it appears that South Plant employees had skin rashes affecting more parts of their bodies than those of West Plant employees.

The skin rash type most often reported at the South Plant was red, itchy skin, and at the West Plant, dry cracked skin (Table XVII), but the differences in prevalences between the two plants for these types of rash were not statistically significant. Rash characterized by red skin and blisters was reported more than twice as often at the South Plant than at the West Plant ( $43 \%$ vs $18 \%, X^{2}=$ $6.26, p<0.025)$. Differences in prevalence between the two plants for other types of rash were not statistically significant. 
Page 21 - Health Hazard Evaluation Determination Report No. HETA 82-358

Smokers at the West Plant reported slightly more respiratory symptoms than did non-smokers for all symptoms; at the South Plant this was also true except for cough (Table XVIII). Except for cough, former smokers had symptom prevalences greater than non-smokers. At the South Plant, former smokers tended to have symptom prevalences intermediate between those of smokers and non-smokers, whereas at the West Plant, their prevalences tended to be greater than those of smokers, with the exception of cough. None of those differences was statistically significant, except for the differences at the West Plant for shortness of breath between former members and non-smokers, and for cough between current and former smokers.

The exposure ranges, means, and medians were calculated for each group using total airborne metal concentrations including $\mathrm{Co}, \mathrm{Cu}, \mathrm{Cr}, \mathrm{Ni}, \mathrm{Pb}$, and $\mathrm{Zn}$ from personal samples collected during the NIOSH survey. The high exposure group included operators, helpers, and laborers from the West Plant. Their range, mean, and median exposures were 58 $\mathrm{ug} / \mathrm{m}^{3}$ to $17,799 \mathrm{ug} / \mathrm{m}^{3} ; 2,810 \mathrm{ug} / \mathrm{m}^{3}$; and $402 \mathrm{ug} / \mathrm{m}^{3}$, respectively. The medium exposure group included operators, helpers, and laborers from the South Plant, and maintenance workers from the West Plant. Their range, mean, and median exposures to the total airborne metals were $94 \mathrm{ug} / \mathrm{m}^{3}$ to $919 \mathrm{ug} / \mathrm{m}^{3} ; 325 \mathrm{ug} / \mathrm{m}^{3} ; 179 \mathrm{ug} / \mathrm{m}^{3}$, respectively. The low exposure group was composed of warehousemen, forklift operators, and electricians from both plants. These workers were estimated by the NIOSH industrial hygienist to have the lowest exposure.

The high and medium exposure groups had similar symptom prevalences, however, the number of employees reporting no symptoms was significantly lower for the high exposure group $\left(X_{2}=4.72, p<0.05\right)$. Both groups reported each individual symptom significantly more often than the low exposure group (Table XIX). This suggests that once a "medium" exposure is reached, further increases in exposure do not increase symptom prevalences.

\section{Record Review}

Among the 43 occurrences of 111 nesses and/or deaths, there were two lung cancers and one case each of skin, blood and salivary gland cancer. The company's retirement benefit death records revealed six additional cancer cases: one each of skin, colon, non-Hodgkins lymphoma, stomach, and one unknown type. Company health insurance carriers did not have any additional cancer cases in their records. The number and distribution of cancer cases identified do not appear to be remarkable. 
Page 22 - Health Hazard Evaluation Determination Report No. HETA 82-358

Almost half of the pulmonary function tests (PFT's) were interpreted in company records as slightly to severely abnormal. Test methods and criteria for interpretation were apparently adequate, except that a test did not necessarily require three acceptable trials; the test was ended as soon as two trials agreed within 10\%. Company officials indicated that each employee was notified personally of his or her PFT results.

VII. DISCUSSION AND CONCLUSION

A. Environmental

Based on the results of this investigation. NIOSH concludes that a health hazard did exist for South Plant employees from exposures to nickel. Nickel concentrations on a 1133 personal samples were above the NIOSH recommended criterion. Every employee who was evaluated for exposure to metals, including employees who were not working in nickel production areas, had an airborne nickel value above the NIOSH criterion. The average exposure was $126 \mathrm{ug} / \mathrm{m}^{3}$ $(S . D .=159)$. Personal sample results for all materials are summarized in table XVIII. Nickel was the only material in excess of current occupational exposure criteria on personal samples. Ionizing radiation values also indicate a potential for employee exposures above the current criterion as well as a potential ingestion hazard. Area sampling results also indicated a potential health hazard from exposure to chromium VI.

Finding detectable levels of chromium VI on area samples indicate that some of the total chromium on personal samples is chromium VI. The environmental criteria for exposure to chromium VI is dependant on its solubility, with water insoluble compounds being considered potential human carcinogens. One of the chromium exposures in Table III could have exceeded the NIOSH recommended standard for noncarcinogenic chromium VI $\left(25 \mathrm{ug} / \mathrm{m}^{3}\right)$, and several could have exceeded the carcinogenic chromium VI criterion $\left(1 \mathrm{ug} / \mathrm{m}^{3}\right)$. Both OSHA and ACGIH criteria distinguish between copper fume and dust. The NIOSH investigators believe that in general, the exposures are more to dust than fume, however, some jobs may indeed involve exposure to copper fume (i.e. heating copper above its melting point).

Production of the depleted uranium catalyst began in Tate 1983. Subsequent to the last NIOSH survey, the Kentucky Cabinet for Human Resources made several inspections of the production area. This group (under an NRC agreement) has responsibility for insuring that United CataTysts meets the liscense (no. SM-6-92) requirements, which include environmental monitoring, biological monitoring of employees, and proper handling of waste material. 
Page 23 - Health Hazard Evaluation Determination Report No. HETA 82-358

Comments by management and employees that some improvements had occurred in the general working conditions are consistent with visible observations of the plant environment. There are, however, many additional improvements needed, to help improve working conditions at the South Plant.

Major revisions are needed in the plant respiratory protection program, general housekeeping, maintenance of the plant's engineering controls, and employee training and education programs. Some improvements were noted subsequent to the intial follow-up survey. The improvements serve as a good beginning but much remains to be done.

The NIOSH investigators were unable to find other published articles discussing environmental/medical evaluations in nickel/chromium/copper catalyst producing facilities.

There are published articles of environmental/medical evaluations in facilities producing other types of catalyst including at least one previous health hazard evaluation. 17 Additionally, there are publications discussing the potential hazards in catalyst manufacturing in genera 1, as well as, specific catalyst materials. $13,18-19$

B. Medical

Since symptoms reported at both plants have previously been reported among individuals having similar exposures, and since in genera 1, exposures measured at the West Plant were higher than those measured at the South Plant, one would expect symptom prevalences at the West Plant to be higher than those at the South Plant. The questionnaire survey, however, failed to show West Plant prevalences to be higher than those at the South Plant. In fact, the only symptom reported significantly more often at the West Plant was skin rash. The lower prevalence of nasal sores and similar prevalences of the other symptoms at the West Plant is unexpected, given the higher over all exposures.

The skin rash characteristics and locations reported most often at the South Plant (see Table XIV and XV), which include red, itchy, dry skin with red blisters, thickened patches, and color changes on the hands, arms, and face, are compatible with (but not specific for) nickel dermatitis in its various stages. 20 However, nickel dermatitis involves immunologic (allergic) hypersensitization and would thus not be expected at the prevalences of rash found in this survey $127 \%$ and $39 \%$ at the South Plant and West Plant, respectively). Furthermore, if nickel exposure is arguably higher at the South Plant, the higher prevalence of rash at the West Plant is not consistent with the rashes, in general, being nickel 
Page 24 - Health Hazard Evaluation Determination Report No. HETA 82-358

dermatitis. Therefore, while there may possibly be cases of nicke] dermatitis at these plants, this survey provides no documentation of this and suggests that, in general, the reported rashes have some other etiology.

Cracked fingernails, reported more often at the West PTant where higher chromium levels were measured, can be caused by chromium exposure 10 , and several West Plant employees indicated that their dry cracked fingernails were stained yellow, which is characteristic of those associated with chromium exposure in the past.

On the basis of the relationship between estimated exposure level and symptoms, and because the reported symptoms are consistent with the exposures occurring at United Catalyst, NIOSH conciudes that symptoms reported among United Catalyst employees are, at least in part, work related. Considering the documentation of acute symptoms and overexposures to one carcinogen (nicke1), and a potential overexposure to a second carcinogen (chromium VI), implementation of corrective measures should begin immediately. 10,11

VIII. RECOMMENDATIONS

1. Management should implement a program to educate the employees of the hazards associated with the materials that they work with. They will be more able to follow safe work practices if they understand why they are asked to perform tasks using specific precautions.

2. In conjunction with recommendation number 1 , an identification system should be developed to insure that all employees are aware of the potential hazards associated with the various materials they work with. The system should coordinate specific hazards listed on material containers with additional information (i.e. material safety data sheets) available at the plant. The requirements of the OSHA Hazardous Communication Standard must be met. Guidelines for developing an identification system are presented in NIOSH's "An Identification System for Occupationally Hazardous Materials" criteria document. 21,22

3. Management should modify their current employee monitoring program so that the various job classifications are evaluated for specific hazards (i.e. nicke1, chromium) rather than just for total and/or respirable particulate. Sampling and analytical methods for the various materials evaluated at the South Plant are available in the new NIOSH Manual of Analytical Methods, 23,24 
Page 25 - Health Hazard Evaluation Determination Report No. HETA 82-358

4. The respiratory protection program needs improvements in many areas. The program must meet the requirement of the OSHA Standard (CFR 1910.134).25 Guidelines for establishing an acceptable program are presented in NIOSH's "A Guide to Industrial Respiratory Protection".26 One change which should be a priority would be to have one individual at the South Plant assigned responsibility for the entire program. This individual could be under the direction of the company's Industrial Hygiene and Safety Department. Needed improvements include the following:
a. A centralized storage area incorporating separate storage compartments for each individual's non-disposable respirators.
b. Maintenance and cleaning of all non-disposable respirators.
c. Fit testing of each employee who wears respiratory protection (including disposable respirators).
d. An employee training program explaining the purpose of respiratory protection and proper techniques for wearing and inspecting respirators.

5. The Engineering Control Program should be improved by incorporating periodic evaluations of all equipment. The evaluation should include visual inspections of all engineering controls as well as measurements of hood and duct airflow characteristics. Specific examples of engineering control problems discussed in this or earlier interim reports should be corrected by management, if they have not already been corrected. Some specific examples are:
a. Installation of a fiuid level indicator on the stainless steel tank in Building 1 (1st floor).
b. The short hose connecting the X-215 furnace with the screener should be repaired or replaced.

6. All barrel and other storage and transport vessels should be covered to reduce airborne emissions. Additionally, all drum-filling operations should initially be equipped with gasketed covers. Future efforts should include exhausting the drum filling operations; this will help reduce airborne emissions. Exhausting drum filling operations is discussed in the ACGIH Industrial Ventilation Manua 1.27 
Page 26 - Health Hazard Evaluation Determination Report No. HETA 82-358

7. At a minimum, the requirements of the Kentucky Radioactive Materials License should be met. Some of the more important safeguards for monitoring and controlling the potential hazard are: (1) environmental and biological monitoring of employees involved in production of the depleted uranium catalyst, (2) designation and enforcement of the production area as a "Restricted Area", (3) eliminating, through engineering controls the spread of radioactive material from the production area into other areas.

8. Plant housekeeping should be improved to help reduce the spread of hazardous materials. Special attention is needed for the bathroom and Tunchroom facilities.

9. All emergency eye wash stations, showers, and drinking fountains should be maintained in a sanitary condition. Eye washes and showers must be accessible if they are to be utilized during an emergency. Additionally, these items should operate automatically after being turned on. Thus, water hoses are not suitable replacements.

10. Welding operations should be partitioned off and screens used to protect nearby employees from eye irritation.

11. A medical surveillance program should be provided to all occupationally exposed employees, it should include:

a. medical and work histories, paying particular attention to skin conditions or allergies, respiratory illnesses, and smoking histories;

b. preplacement and periodic physical examinations of the upper respiratory tract membranes for evidence of irritation, bleeding, ulcerations, or perforations; of the lungs for evidence of respiratory impairment; and of the skin for dermatitis;

c. an assessment of the employee's ability to use positive or negative pressure respirators.

d. baseline pulmonary function tests. Additional routine pulmonary function tests are not needed for the exposures identified by NIOSH, but they should be utilized as needed to further evaluate problems detected by the routine medical surveillance. 
Page 27 - Health Hazard Evaluation Determination Report No. HETA 82-358

\section{REFERENCES}

1. National Institute for Occupational Safety and Health. NIOSH manual of analytical methods. Vol 1, 2nd ed. Cincinnati, Ohio: National Institute for Occupational Safety and Health, 1977. (DHEW (NIOSH) publication no. 77-157-A).

2. National Institute for Occupational Safety and Health. NIOSH manual of analytical methods. Vol 6, 2nd ed. Cincinnati, Ohio: National Institute for Occupational Safety and Health, 1980. (DHHS (NIOSH) publication no. 80-125).

3. National Institute for Occupational Safety and Health. NIOSH manual of analytical methods. Vol 4, 2nd ed. Cincinnati, Ohio: National Institute for Occupational Safety and Health, 1978. (DHEW (NIOSH) publication no. 78-175).

4. National Institute for Occupational Safety and Health. NIOSH manual of analytical methods. Vol 7, 2nd ed. Cincinnati, Ohio: National Institute for Occupational Safety and Health, 1981. (DHHS (NIOSH) publication no. 82-100).

5. National Institute for Occupational Safety and Health. NIOSH/OSHA occupational health guidelines for chemical hazards. Cincinnati, Ohio: National Institute for Occupational Safety and Health, 1981. (DHHS (NIOSH) publication no. 81-123).

6. American Conference of Governmental Industrial Hygienists. Threshold limit values for chemical substances and physical agents in the workroom environment with intended changes for 1984-85. Cincinnati, Ohio: ACGIH, 1984.

7. American Conference of Governmental Industrial Hygienists. Documentation of the threshold limit values. 4th ed. Cincinnati, Ohio: ACGIH, 1980.

8. Occupational Safety and Health Administration. OSHA safety and health standards. 29 CFR 1910.1000. Occupational Safety and Health Administration, revised 1980.

9. National Institute for Occupational Safety and Health. Occupational diseases: a guide to their recognition. Revised ed. Cincinnati, Ohio: National Institute for Occupational Safety and Health, 1977. (DHEW (NIOSH) publication no. 77-181).

10. National Institute for Occupational Safety and Health. Criteria for a recommended standard: occupational exposure to chromium VI. Cincinnati, Ohio: National Institute for Occupational Safety and Health, 1976. (DHEW publication no. (NIOSH) 76-129). 
Page 28 - Health Hazard Evaluation Determination Report No. HETA 82-358

11. International Labor Office. Encyclopedia of occupational health and safety. Vol. 2/L-Z Geneva: International Labor Office, 1983.

12. National Institute for Occupational Safety and Health. Criteria for a recommended standard: occupational exposure to inorganic nicke1. Cincinnati, Ohio: National Institute for 0ccupational Safety and Health, 1977. (DHEW publication no. (NIOSH) 77-164).

13. International Labor Office. Encyclopedia of Occupational Health and Safety. Vol. 1/A-K Geneva: International Labor Office, 1983.

14. National Institute for Occupational Safety and Health. Supplement to the NIOSH certified equipment list. Morgantown, WV: National Institute for Occupational Safety and Health, 1981.

15. Drager. Detector tube handbook. 5th ed. Lubeck, Federal Republic of Germany: Drager February 1983.

16. National Institute for 0ccupational Safety and Health. Certified equipment list-as of September 1, 1983. Cincinnati, Ohio:

National Institute for Occupational Safety and Health, 1983. (DHHS publication No. [NIOSH] 83-122).

17. National Institute for 0ccupational Safety and Health. Health hazard evaluation report no. HETA 81-089-965. Cincinnati, Ohio: National Institute for Occupational Safety and Health, 1981.

18. National Institute for 0ccupational Safety and Health. Current intelligence bulletin 26--NIAX catalyst ESN. Cincinnati, Ohio: National Institute for Occupational Safety and Health, 1978. (DHHS (NIOSH) publication no. 78-157).

19. National Institute for Occupational Safety and Health. Special hazard review with control recommendations: 4,4'-methy lenebis (2-chloroaniline). Cincinnati, Ohio: National Institute for Occupational Safety and Health, 1978. (DHHS (NIOSH) publication no. 78-188).

20. Proctor NH., Hughes JP. Chemical Hazards of the Uorkplace. Philadelphia, PA: J.B. Lippencott Company, 1978.

21. National Institute for 0ccupational Safety and Health. Criteria for a recommended standard: an identification system for occupationally hazardous materials. Cincinnati, Ohio: National Institute for Occupational Safety and Health, 1975. (DHEW publication no. (NIOSH) 75-126). 
Page 29 - Health Hazard Evaluation Determination Report No. HETA 82-358

22. Occupational Safety and Health Administration. Hazard Communication: final rule. 29 CFR 1910.1200. Occupational Safety and Health Administration, Federal Register. November 1983.

23. National Institute for Occupational Safety and Health. Manual of Analytical Methods. Vo1.1, 3rd ed. Cincinnati, Ohio: National Institute for Occupational Safety and Health, 1984. (OHHS publication No. [NIOSH] 84-100).

24. National Institute for Occupational Safety and Health. Manual of Analytical Methods. Vol. 2, 3rd ed. Cincinnati, Ohio: National Institute for Occupational Safety and Health, 1984. (DHHS publication No. [NIOSH] 84-100).

25. Occupational Safety and Health Administration. OSHA safety and health standards. 29 CFR 1910.134. Occupational Safety and Health Administration, revised June 1981.

26. National Institute for Occupational Safety and Health. A Guide to Industrial Respiratory Protection. Cincinnati, Ohio: National Institute for Occupational Safety and Health, 1976. (DHHS publication No. [NIOSH] 76-189).

27. American Conference of Governmental Industrial Hygienists. ACGIH industrial ventilation: a manual of recommended practice. ACGIH Committee on Industrial Ventilation: Lansing, Michigan, 1982.

$X$. AUTHORSHIP AND ACKNOWLEDGEMENTS

Report Prepared by:

John N. Zey, M.S. Industria? Hygienist Industrial Hygiene Section

Cheryl Lucas, M.S. Medical officer Medical Section

Field Assistant:

Environmenta 1 :

Ken Wallingford, I.H. Industrial Hygiene Section

Ray Ruhe, I.H. Industrial Hygiene Section

Larry Reed, I.H. Industrial Hygiene Section

Warren Myers, I.H. Division of Safety Research Morgantown, West Virginia 
Page 30 - Hea 1 th Hazard Evaluation Determination Report No. HETA 82-358

\begin{tabular}{|c|c|}
\hline Equipment Preparation: & $\begin{array}{l}\text { Larry DeArmond } \\
\text { Laboratory Technician } \\
\text { Industrial Hygiene Section }\end{array}$ \\
\hline & $\begin{array}{l}\text { Mike King } \\
\text { Laboratory Technician } \\
\text { Industrial Hygiene Section }\end{array}$ \\
\hline Analytical Support: & $\begin{array}{l}\text { NIOSH Contract Lab } \\
\text { Utah Biomedica } 1 \text { Test Lab } \\
520 \text { Wakara Way } \\
\text { Sa1t Lake City, Utah } \\
\text { Measurement Research Support Branch } \\
\text { NIOSH Laboratory } \\
\text { Cincinnati, Ohio }\end{array}$ \\
\hline Originating Office: & $\begin{array}{l}\text { Hazard Evaluations and Technical } \\
\text { Assistance Branch } \\
\text { Division of Surveillance, Hazard } \\
\text { Evaluations, and Field Studies }\end{array}$ \\
\hline Report Typed By: & $\begin{array}{l}\text { Stephanie M. Harris } \\
\text { Clerk Typist } \\
\text { MedicaT Section }\end{array}$ \\
\hline & $\begin{array}{l}\text { Jacqueline Grass } \\
\text { Clerk Typist } \\
\text { Industrial Hygiene Section }\end{array}$ \\
\hline Acknowledgement: & $\begin{array}{l}\text { Mitchell Singal, M.D., HETAB, NIOSH } \\
\text { For assistance in preparing the } \\
\text { final report. } \\
\text { Mr. Robert Hughes, DPSE, NIOSH } \\
\text { For suggestions on engineering } \\
\text { controls }\end{array}$ \\
\hline
\end{tabular}


Page 31 - Health Hazard Evaluation Determination Report No. HETA 82-358

$X$. DISTRIBUTION AND AVAILABILITY OF REPORT

Copies of this report are currently available upon request from NIOSH, Division of Standards Development and Technology Transfer, Publications Dissemination Section, 4676 Columbia Parkway, Cincinnati, Ohio 45226. After 90 days, the report will be available through the National Technical Information Service (NTIS), 5285 Port Roya 1, Springfield, Virginia 22161. Information regarding its availability through NTIS can be obtained from NIOSH Publications Office at the Cincinnati address. Copies of this report have been sent to:

1. United Cataiysts, Inc.

2. Teamsters, Union Local No. 89

3. Kentucky Department of Labor

4. NIOSH, Region IV

5. OSHA, Region IV

For the purpose of informing the 135 affected employees, copies of this report shall be posted by the employer in a prominent place accessible to the employees for a period of 30 calendar days. 
TABLE 1

Sampling and Analytical Methods

United Catalysts Inc.

South Plant

Louisville, Kentucky

HETA $82-358$

\begin{tabular}{|c|c|c|c|}
\hline Contaminant & $\begin{array}{l}\text { Flow Rate } \\
(1 \mathrm{pm})\end{array}$ & Sampling Method & Analytical Hethod \\
\hline Sulfuric Acid & 0.1 & SiTica Gel Tube & NIOSH Metod Ho. P\&CAM Ho. 339 \\
\hline Ammonia & 0.05 & $\begin{array}{l}\text { Sulfuric-Acid Treated } \\
\text { Silfca Gel Tube Preceded } \\
\text { By A Mixed Cellulose Ester } \\
\text { Membrane Filter }\end{array}$ & Colorimetric Automated Phenate \\
\hline $\begin{array}{l}\text { Crystalline Silica } \\
\text { (Quartz and Cristobalite) }\end{array}$ & $\begin{array}{l}\text { 1.7 Personal } \\
9.0 \text { High-Volume }\end{array}$ & Polyvinyl Chloride Filter & MIOSH Method No. P\&CAM No. 259 \\
\hline Respirable Particulate & 1.7 & Polyvinyl Chloride Filter & Gravimetric \\
\hline Amines & 0.1 & $\begin{array}{l}\text { Citric Acld-Coated } \\
\text { Silica Gel Tube }\end{array}$ & $\begin{array}{l}\text { A11phatic Amines }=\text { NIOSH } \\
\text { Method No. P\&CAM } 276 \\
\text { Aromatic Amines }=\text { NIOSH } \\
\text { Method Ho. P\&CAM } 168\end{array}$ \\
\hline Grab Samples for Ammonia & - & $\begin{array}{l}\text { Direct-Reading Indicator } \\
\text { Tubes }\end{array}$ & Direct Reading \\
\hline Chrami um VI & 2.0 & Polyvinyl Chloride Filter & $\begin{array}{l}\text { Colorimetry Via NIOSH Method } \\
\text { Ho. P\&CAM } 319\end{array}$ \\
\hline Nickel and Chromtum & 1.5 & $\begin{array}{l}\text { Mixed Cellulose Ester } \\
\text { Membrane Filter }\end{array}$ & $\begin{array}{l}\text { Atomic Absorption Via } \\
\text { NIOSH Method Ho. P\&CAM } 173\end{array}$ \\
\hline $\begin{array}{l}\text { Twenty-eight separate metals } \\
\text { including nickel. chromium, } \\
\text { lead, and copper }\end{array}$ & 1.5 & $\begin{array}{l}\text { Mixed Cellulose Ester } \\
\text { Meubrane Filter }\end{array}$ & $\begin{array}{l}\text { Inductively coupled plasma- } \\
\text { a tomic emission spectroscopy }\end{array}$ \\
\hline Iontzing Radiation & & $\begin{array}{l}\text { 1. Mini Con-rad (Mode1 3032) } \\
\text { 2. Ludlum Measurements Inc. } \\
\text { Model } 3 \text { Survey Meter } \\
\text { 3. Ludlum Measurements, Inc } \\
\text { Model } 12 \text { Count Ratemeter }\end{array}$ & $\begin{array}{l}\text { Direct Reading } \\
\text { Direct Reading } \\
\text { Direct Reading }\end{array}$ \\
\hline
\end{tabular}


TABLE II

Environmental Criteria and Associated Health Effects

United Catalysts Inc.

South Plant

Louisville, Kentucky

HETA $82-358$

\begin{tabular}{|c|c|c|c|c|}
\hline \multirow[b]{2}{*}{ Contaminant } & \multicolumn{3}{|c|}{$\begin{array}{l}\text { Environmental Criteria } \\
\left(\mathrm{mg} / \mathrm{m}^{3} \text { unless otherwise noted) }\right.\end{array}$} & \multirow[b]{2}{*}{ Associated Health Effects } \\
\hline & OSHA & NIOSH & ACGIH & \\
\hline Nickel & 1 & 0.015 & 1 & $\begin{array}{l}\text { Lung and nasal cancer, } \\
\text { dermatitis, pneumonitis } \\
\text { (inflammation of the } \\
\text { lungs), and allergic } \\
\text { asthma }\end{array}$ \\
\hline $\begin{array}{l}\text { Chromium VI (carcinogenic, } \\
\text { water insoluble) }\end{array}$ & & 0.001 & 0.05 & Lung cancer \\
\hline $\begin{array}{l}\text { Chromium VI } \\
\text { (noncarcinogenic, water } \\
\text { soluble) }\end{array}$ & 0.05 & 0.025 & 0.05 & $\begin{array}{l}\text { Respiratory tract } \\
\text { irritation, kidney and } \\
\text { Tiver damage }\end{array}$ \\
\hline $\begin{array}{l}\text { Chromium Meta 1, +2 and }+3 \\
\text { compounds }\end{array}$ & $\begin{array}{l}0.5 \text { (sol. chronic and } \\
\text { chromous salts) } 1 \\
\text { (Metal and insoluble }\end{array}$ & salts) & 0.5 & Dermatitis \\
\hline \multirow{2}{*}{$\begin{array}{l}\text { Crystalline Silica } \\
\text { (respirable) }\end{array}$} & $10 \mathrm{mg} / \mathrm{m}^{3}$ & 0.05 & $10 \mathrm{mg} / \mathrm{m}^{3}$ & Silicosis \\
\hline & $\% \mathrm{SiO}_{2}+2$ & & $\% \mathrm{SiO}_{2}+2$ & \\
\hline $\begin{array}{l}\text { Cobalt (meta 1, fume, and } \\
\text { dust) }\end{array}$ & $\begin{array}{l}0.05 \\
0.01=S T E L\end{array}$ & N.A. & 0.1 & $\begin{array}{l}\text { Allergic dermatitis, } \\
\text { possible chronic } \\
\text { interstitial pneumonitis }\end{array}$ \\
\hline
\end{tabular}


TABLE II (continued)

\begin{tabular}{|c|c|c|c|c|}
\hline \multirow[b]{2}{*}{ Contaminant } & \multicolumn{3}{|c|}{$\begin{array}{c}\text { Environmental Criteria } \\
\left(\mathrm{mg} / \mathrm{m}^{3} \text { unless otherwise noted }\right)\end{array}$} & \multirow[b]{2}{*}{ Associated Hea 1 th Effects } \\
\hline & OSHA & NIOSH & ACGIH & \\
\hline Ammonia & 35 & $\begin{array}{l}34.8 \\
\text { (for } 5 \text {-min } \\
\text { period) }\end{array}$ & 18 & $\begin{array}{l}\text { Eye damage, irritation to } \\
\text { eyes and respiratory } \\
\text { tract }\end{array}$ \\
\hline Sulfuric Acid & 1 & 1 & 1 & $\begin{array}{l}\text { Pulmonary edema, dental } \\
\text { erosion, mucous membranes } \\
\text { irritation }\end{array}$ \\
\hline Nitric Oxide & 30 & 30 & 30 & $\begin{array}{l}\text { Drowsiness; eyes, nose, } \\
\text { and throat irritation }\end{array}$ \\
\hline Nitrogen Dioxide & $\begin{array}{l}\text { (ceiling value not } \\
\text { to be exceeded) }\end{array}$ & $\begin{array}{c}1.8 \\
(15-m i n \\
\text { ceiling value) }\end{array}$ & 6 & $\begin{array}{l}\text { Pulmonary edema, } \\
\text { tachycardia, dyspnea, } \\
\text { cough, eye irritation, } \\
\text { chest pain }\end{array}$ \\
\hline Copper & $\begin{array}{l}0.1 \text { (Fume) } \\
1 \text { (dusts and } \\
\text { mists) }\end{array}$ & - & $\begin{array}{l}0.2 \text { (fume) } \\
1 \text { (Dusts } \\
\text { and mists) }\end{array}$ & $\begin{array}{l}\text { Mucous membrane } \\
\text { irritation, nasal septum } \\
\text { perforation, eye } \\
\text { irritation, dermatitis }\end{array}$ \\
\hline Lead & 0.05 & 0.05 & 0.15 & $\begin{array}{l}\text { Insomnia, constipation, } \\
\text { anemia, gingival lead } \\
\text { line, low body weight, } \\
\text { abdominal pain }\end{array}$ \\
\hline
\end{tabular}


TABLE III

Airborne Concentrations of Metals

United Catalysts Inc.

South Plant

Louisville, Kentucky

HETA 82-358

February 15-17, 1983

\begin{tabular}{|c|c|c|c|c|c|c|c|c|}
\hline \multirow[b]{2}{*}{ Location/Job } & \multirow[b]{2}{*}{$\begin{array}{l}\text { Sample } \\
\text { Time }\end{array}$} & \multirow[b]{2}{*}{ Date } & \multirow[b]{2}{*}{$\begin{array}{l}\text { Volume } \\
\text { (Liters) }\end{array}$} & \multicolumn{5}{|c|}{ Concentration $\left(\mathrm{ug} / \mathrm{m}^{3}\right)$} \\
\hline & & & & Co & $\mathrm{Cu}$ & $\mathrm{Cr}$ & $\mathrm{Ni}$ & $\mathrm{Pb}$ \\
\hline Bldg. 2, Nickel Oper. & $0755-1430$ & $2-15$ & 593 & - & - & LLD & 105 & - \\
\hline B1dg. 2, H-230, Oper. & $0754-1430$ & $2-15$ & 594 & - & - & LLD & 141 & - \\
\hline Bldg. 2, Nickel Oper. Helper & $0758-1430$ & $2-15$ & 588 & - & - & LLD & 94 & - \\
\hline B1dg. 2, Nickel Oper. & $0732-1430$ & $2-16$ & 627 & - & - & LLD & 287 & - \\
\hline Bldg. 2, Nickel Oper. Helper & $0720-1429$ & $2-16$ & 644 & - & - & LLD & 132 & - \\
\hline B1dg. 2, Nickel Oper. & $0658-1432$ & $2-17$ & 681 & - & - & LLD & 206 & - \\
\hline Bldg. 2, Double Cone Oper. & $0701-1429$ & $2-17$ & 672 & - & - & 5 & 179 & - \\
\hline Bldg. 2, Pulvacron Oper. & $0800-1355$ & $2-17$ & 533 & - & - & LLD & 638 & - \\
\hline $\begin{array}{l}\text { Bidg. 1, Most of Day, Bldg. } \\
\text { 2, } 30 \text { Min., Sweeper }\end{array}$ & $0725-1420$ & $?-15$ & 623 & 5 & 85 & 6 & 51 & LLD \\
\hline $\begin{array}{l}\mathrm{B} 1 \mathrm{dg} .2 \text {, Clean Up, Used } \\
\mathrm{H}_{2} \mathrm{O} \text { Hose }\end{array}$ & $0705-1358$ & $2-15$ & 620 & 4 & 45 & 7 & 369 & LLD \\
\hline Bldg. 1, Sweeper & $0725-1420$ & $2-16$ & 623 & - & - & 10 & 45 & - \\
\hline
\end{tabular}


TABLE III (continued)

\begin{tabular}{|c|c|c|c|c|c|c|c|c|c|}
\hline \multirow[b]{2}{*}{ Location/Job } & \multirow[b]{2}{*}{$\begin{array}{l}\text { Sample } \\
\text { Time }\end{array}$} & \multirow[b]{2}{*}{ Date } & \multirow[b]{2}{*}{$\begin{array}{l}\text { Volume } \\
\text { (Liters) }\end{array}$} & \multicolumn{6}{|c|}{ Concentration $\left(\mathrm{ug} / \mathrm{m}^{3}\right)$} \\
\hline & & & & Co & $\mathrm{Cu}$ & $\mathrm{Cr}$ & Ni & $\mathrm{Pb}$ & \\
\hline $\begin{array}{l}\text { Bidg. 1, Two Hours, B1dg. 2, } \\
6 \text { Hours, Laborer, Clean Up }\end{array}$ & $0754-1407$ & $2-16$ & 560 & 4 & 12 & LLD & 680 & LLD & \\
\hline $\begin{array}{l}\text { B1dg. 2, Clean Up, Used } \\
\mathrm{H}_{2} \mathrm{O} \text { Hose, } 2 \text { Hours Cleaning } \\
\text { X215 Furnace }\end{array}$ & $0740-1430$ & $2-17$ & 615 & 5 & 674 & 3 & 146 & LLD & \\
\hline $\begin{array}{l}\text { Maintenance, B 1dg. 1, G64 } \\
\text { Area, Welding } 4 \text { Hours }\end{array}$ & $0752-1413$ & $2-15$ & 572 & 5 & 19 & 6 & 49 & 7 & \\
\hline $\begin{array}{l}\text { Maintenance, Bldg. } 1, \text { G64 } \\
\text { Area, Near Welding } 4 \text { Hours }\end{array}$ & 0753-1411 & $2-15$ & 567 & 7 & 18 & 5 & 36 & 4 & v \\
\hline B1dg. 1, G3 Helper & $0704-1354$ & $2-15$ & 615 & - & - & 7 & 153 & - & \\
\hline B1dg. 1, G3 Laborer & $0702-1352$ & $2-15$ & 615 & 3 & 80 & 17 & 54 & LLD & \\
\hline B1dg. 1, G3 Oper., Finish End & $0705-1418$ & $2-15$ & 650 & - & - & 15 & 42 & - & \\
\hline B1dg. 1, G3 Oper., Front End & $0706-1355$ & $2-15$ & 614 & - & - & 13 & 26 & - & \\
\hline B1dg. 1, G3 Laborer & $0700-1355$ & $2-15$ & 623 & 4 & 161 & 37 & 112 & LLD & \\
\hline B1dg. 1, G3 Helper & $0747-1410$ & $2-16$ & 575 & - & - & 12 & 28 & - & \\
\hline B1dg. 1, G64 Senior Oper. & $0703-1418$ & $2-16$ & 650 & - & - & 9 & 35 & - & \\
\hline B1dg. 1. 1101 Oper. Helper & $0703-1418$ & $2-17$ & 653 & - & - & 15 & 46 & - & \\
\hline B1dg. 1, G64 Oper. & $0708-1424$ & $2-17$ & 654 & - & - & 9 & 29 & - & \\
\hline Bldg. 1, G64 Oper. Helper & $0706-1423$ & $2-17$ & 656 & - & - & 8 & 44 & - & \\
\hline
\end{tabular}


TABLE III (continued)

\begin{tabular}{|c|c|c|c|c|c|c|c|c|}
\hline \multirow[b]{2}{*}{ Location/Job } & \multirow[b]{2}{*}{$\begin{array}{l}\text { Sample } \\
\text { Time }\end{array}$} & \multirow[b]{2}{*}{ Date } & \multirow{2}{*}{$\begin{array}{l}\text { Volume } \\
\text { (Liters) }\end{array}$} & \multicolumn{5}{|c|}{ Concentration $\left(\mathrm{ug} / \mathrm{m}^{3}\right)$} \\
\hline & & & & Co & $\mathrm{Cu}$ & $\mathrm{Cr}$ & $\mathrm{Ni}$ & $\mathrm{Pb}$ \\
\hline B1dg. 1, 1101 0per. & $0711-1428$ & $2-17$ & 656 & - & - & 12 & 44 & - \\
\hline Bldg. 1, 218 Pill Area Oper. & $0723-1412$ & $2-16$ & 614 & - & - & 10 & 23 & - \\
\hline B1dg. 1, 201 Oper. Helper & $0710-1414$ & $2-17$ & 636 & - & - & 14 & 41 & - \\
\hline $\begin{array}{l}\text { Maintenance, B1dg. 1, G64 } \\
\text { Pellet Mills }\end{array}$ & 0706-1409 & $2-16$ & 635 & - & - & 9 & 24 & - \\
\hline Ma intenance & $0736-1429$ & $2-17$ & 620 & 4 & 22 & 11 & 38 & LLD \\
\hline $\begin{array}{l}\text { Maintenance, Bldg. } 1 \text { and } \\
\text { Bldg. 2, Welding }\end{array}$ & $0829-1422$ & 2-17 & 530 & 5 & 40 & 22 & 150 & 2 \\
\hline $\begin{array}{l}\text { B1dg. 1, Fork Truck Oper., } \\
\text { All Over }\end{array}$ & $0800-1355$ & $2-15$ & 530 & 4 & 84 & 10 & 52 & LLD \\
\hline $\begin{array}{l}\text { Bldg. 1, Fork Truck Oper., } \\
\text { All Over }\end{array}$ & $0721-1415$ & $2-16$ & 621 & 7 & 80 & 13 & 49 & LLD \\
\hline \multirow{3}{*}{$\begin{array}{l}\text { Environmental Criteria for } \\
\text { Normal Shift, } 8 \text { Hours for OSHA } \\
\text { and ACGIH, Up to } 10 \text { Hours for } \\
\text { NIOSH }\end{array}$} & & OSHA & & 100 & 1000 & 1000 & 1000 & 50 \\
\hline & & NIOSH & & $\mathrm{N}$ & $\mathrm{N}$ & $\mathrm{N}$ & 15 & 50 \\
\hline & & ACGIH & & 100 & 1000 & 500 & 1000 & 150 \\
\hline
\end{tabular}

- = Not analyzed for on this sample.

LLD $=$ Below the laboratory limit of detection.

$\mathrm{N}=\mathrm{NIOSH}$ has no specific criterion for this material. 
TABLE IV

Airborne Concentration for Respirable Dust and Crystalline Silica

Personal and Area Samples

United Catalysts Inc.

$$
\text { South Plant }
$$

Louisville, Kentucky

HETA $82-358$

February $15-18,1983$

\begin{tabular}{|c|c|c|c|c|c|c|c|}
\hline \multirow{3}{*}{ Location/Job } & \multirow{3}{*}{$\begin{array}{l}\text { Sample } \\
\text { Time }\end{array}$} & \multirow[b]{3}{*}{ Date } & \multirow{3}{*}{$\begin{array}{l}\text { Volume } \\
\text { (Liters) }\end{array}$} & \multirow{3}{*}{$\begin{array}{l}\text { Type of } \\
\text { Sample }\end{array}$} & \multicolumn{3}{|c|}{ Concentration $\left(\mathrm{mg} / \mathrm{m}^{3}\right)$} \\
\hline & & & & & & Crystal & Tine silica \\
\hline & & & & & Dust & Quartz & Cristobalite \\
\hline B1dg. 1, Oper., H-230 and 1101 & $0755-1427$ & $2-15$ & 658 & Personal & 0.37 & LLD & LLD \\
\hline B1dg. 1, 1101 Oper. Helper & $0756-1415$ & $2-15$ & 644 & Persona 1 & 0.45 & LLD & LLD \\
\hline B1dg. 1, 1101 Oper. Helper & $0712-1411$ & $2-16$ & 712 & Personal & 0.25 & LLD & LLD \\
\hline B1dg. 1, 1101 Area & $0733-1436$ & $2-17$ & 719 & Area & 0.43 & LLD & LLD \\
\hline B1dg. 2, 3rd Floor, H230 Prep Area & $\begin{array}{l}1230-1630 \\
0925-1105\end{array}$ & $\begin{array}{l}2-17 \\
2-18\end{array}$ & 629 & Area & 0.19 & LLD & LLD \\
\hline 81dg. 2, H230, Oper. & $0718-1430$ & $2-16$ & 734 & Persona 1 & 0.48 & LLD & LLD \\
\hline B1dg. 1, 1101, Drumming Area & $0837-1232$ & $2-16$ & 2209 & $\begin{array}{l}\text { Area } \\
\text { High-Volume }\end{array}$ & 0.34 & LLD & LLD \\
\hline Bidg. 1, 1101. Drumming Area & $\begin{array}{l}1235-1510 \\
0607-1436\end{array}$ & $\begin{array}{l}2-16 \\
2-17\end{array}$ & 6242 & $\begin{array}{l}\text { Area } \\
\text { High-Volume }\end{array}$ & 0.46 & 0.01 & LLD \\
\hline
\end{tabular}

Instrumental precision of weighings done at one setting is $0.01 \mathrm{mg}$.

$L L D=$ Below the laboratory lower limit of quantitation ( 0.03 milligrams for both quartz and cristobalite) Environmental Criteria $\left(\mathrm{Mg} / \mathrm{m}^{3}\right)$ : Respirable Dust $=5$ (OSHA and $\mathrm{ACGIH}$ )

Quartz $=\frac{10 \mathrm{mg} / \mathrm{m}^{3}}{\% \mathrm{SiO}_{2}+2}$ (OSHA and ACGIH) 0.05 (NIOSH)

Cristobalite $=$ Use $1 / 2$ the value calculated from the mass formula for quartz (OSHA and ACGIH). 
TABLE V

Airborne Concentrations for Chromium VI

Area Samples

United Catalysts Inc.

South Plant

Louisville, Kentucky

HETA $82-358$

February 16-17, 1983

\begin{tabular}{lcccc}
\hline \multicolumn{1}{c}{ Location } & Sample Time & Date & $\begin{array}{c}\text { Volume } \\
\text { (Liters) } \begin{array}{c}\text { Concentration } \\
\text { (ug/m } 3 \text { ) }\end{array}\end{array}$ \\
\hline B1dg. 1, G64, Pellet Machine & $0739-1425$ & $2-16$ & 812 & 4.2 \\
B1dg. 1, G64, Pellet Machine & $0727-1429$ & $2-17$ & 844 & 4.0 \\
B1dg. 2, 1st Floor, At Double Cone & $0758-1425$ & $2-16$ & 774 & 0.8 \\
B1dg. 2, 1st Floor, At Double Cone & $0758-1442$ & $2-17$ & 808 & 3.7 \\
\hline
\end{tabular}

Laboratory limit of detection $=0.2 \mathrm{ug} / \mathrm{filter}$

Environmental Criteria $\left(\mathrm{ug} / \mathrm{m}^{3}\right):$ NIOSH $=1$ for carcinogenic $\mathrm{cr}+6$

25 for noncarcinogenic $\mathrm{Cr}^{+6}$

ACGIH $=50$ for water soluble and certain water insoluble 
TABLE VI

Airborne Concentrations for SuTfuric Acid $\left(\mathrm{H}_{2} \mathrm{SO}_{4}\right)$

Personal Samples

United Catalysts Inc. South Plant

Louisville, Kentucky

HETA $82-358$

February $16-17,1983$

\begin{tabular}{lcccc}
\hline \multicolumn{1}{c}{ Location/Job } & Sample Time & Date & $\begin{array}{c}\text { Volume } \\
\text { (Liters) }\end{array}$ & $\begin{array}{c}\text { Concentration } \\
\text { (mg/m } 3 \text { ) }\end{array}$ \\
\hline B1dg. 1, G3 Oper. & $0716-1420$ & $2-16$ & 41.3 & LLD \\
B1dg. 1, G3 Oper. & $0714-1419$ & $2-17$ & 41.9 & LLD \\
B1dg. 1, G3 Oper. Helper & $0705-1410$ & $2-17$ & 41.1 & LLD \\
\hline
\end{tabular}

LLD $=$ Below the laboratory 11 mit of detection ( $4 \mathrm{ug} /$ sample)

Environmenta] Criteria $\left(\mathrm{mg} / \mathrm{m}^{3}\right): \quad$ OSHA $=1$

NIOSH $=1$

ACGIH $=1$ 
TABLE VII

Airborne Concentrations for Ammonia

Personal and Area Samples

United Catalysts Inc.

South Plant

Louisville, Kentucky

HETA $82-358$

February 15-17, 1983

\begin{tabular}{|c|c|c|c|c|c|}
\hline Location/Job & $\begin{array}{l}\text { Sample } \\
\text { Time }\end{array}$ & Da te & $\begin{array}{l}\text { Volume } \\
\text { (Liters) }\end{array}$ & $\begin{array}{l}\text { Type of } \\
\text { Sample }\end{array}$ & $\begin{array}{c}\text { Concentration } \\
\left(\mathrm{mg} / \mathrm{m}^{3}\right)\end{array}$ \\
\hline Bldg. 2, 1st Floor, Near Filter Press & $0903-1435$ & $2-16$ & 16.8 & Area & 3.69 \\
\hline B1dg. 2, 3rd Floor, At H-230 Prep Area & $0912-1420$ & $2-16$ & 14.9 & Area & 8.99 \\
\hline 81dg. 2, 3rd Floor, At H-230 Prep Area & $0807-1445$ & $2-17$ & 20.2 & Area & 3.76 \\
\hline Bldg. 2, Nickel Oper. Helper & $0702-1430$ & $2-17$ & 21.8 & Persona 1 & 2.89 \\
\hline B1dg. 2, Oper. & $0704-1430$ & $2-17$ & 21.5 & Persona 1 & 1.67 \\
\hline
\end{tabular}

Laboratory limit of detection $=4 \mathrm{ug} / \mathrm{sample}$

Environmental Criteria $\left(\mathrm{mg} / \mathrm{m}^{3}\right): \quad$ OSHA $=35$

NIOSH = no full shift criterion

$A C G I H=18$ 


\section{TABLE VIII}

Ammonia Concentrations

Collected with Direct-Reading Indicator Tubes

United Catalysts Inc.

South Plant

Louisville, Kentucky

HETA 82-358

February 15 and 17, 1983

\begin{tabular}{|c|c|c|c|}
\hline Location & Time & Date & $\begin{array}{c}\text { Concentration } \\
(\text { ppm) }\end{array}$ \\
\hline $\begin{array}{l}\text { Bldg. 2, 1st Floor, End of Canopy } \\
\text { Hood (Above Filter Press) Away } \\
\text { From Closest Wall }\end{array}$ & 1045 & $2-15$ & 15 \\
\hline $\begin{array}{l}\text { Bldg. 2, 1st Floor, End of Canopy } \\
\text { Hood (Above Filter Press) at End } \\
\text { of Press Nearest the Wa11 }\end{array}$ & $\begin{array}{l}1053 \\
1111\end{array}$ & $\begin{array}{l}2-15 \\
2-15\end{array}$ & $\begin{array}{l}28 \\
18\end{array}$ \\
\hline $\begin{array}{l}\text { Bldg. 2, 3rd Floor, Near Amine } \\
\text { Prep Tank, at Console for } H-230 \\
\text { System }\end{array}$ & 1240 & $2-15$ & 30 \\
\hline $\begin{array}{l}\text { Bldg. 2, At Amine Prep Tank for } \\
\text { H-230 System (System not Running), } \\
\text { 3rd Floor }\end{array}$ & $\begin{array}{l}1210 \\
1215\end{array}$ & $\begin{array}{l}2-17 \\
2-17\end{array}$ & $\begin{array}{l}\text { trace } \\
\text { trace }\end{array}$ \\
\hline $\begin{array}{l}\text { B1dg. 2, At Amine Prep Tank for } \\
\text { H-230 System, 3rd Floor }\end{array}$ & $\begin{array}{l}1258 \\
1303\end{array}$ & $\begin{array}{l}2-17 \\
2-17\end{array}$ & $\begin{array}{l}42 \\
18\end{array}$ \\
\hline
\end{tabular}

Environmental Criteria $(\mathrm{ppm}): \mathrm{NIOSH}=50$ for a 5 -minute period 
TABLE IX

Analysis of Bulk Settled Dust Samples

Percentage of Various Metals (By Wt.)

United Catalysts Inc.

South Plant

Louisville, Kentucky

HETA $82-358$

February 17 and March 2, 1983

\begin{tabular}{|c|c|c|c|c|c|c|}
\hline \multirow[b]{2}{*}{$\begin{array}{l}\text { Location Sample Was } \\
\text { Collected In }\end{array}$} & \multirow[b]{2}{*}{ Da te } & \multicolumn{5}{|c|}{ Percent of Metal } \\
\hline & & Co & $\mathrm{Cu}$ & $\mathrm{Cr}$ & $\mathrm{Ni}$ & $\mathrm{Pb}$ \\
\hline $\begin{array}{l}\text { B1dg. 2, 3rd Floor, At H-230 } \\
\text { Prep Area Sample Collected On } \\
\text { Cross Structural Member } \\
\text { Approx. } 6^{\prime} \text { off Floor }\end{array}$ & $2-17$ & - & 0.045 & 0.015 & $<25$ & - \\
\hline $\begin{array}{l}\text { Bidg. 1, Top of B1dg., At Top } \\
\text { of Process Vesse1 Previously } \\
\text { Used With Depleted Uranium }\end{array}$ & $3-2$ & 3.39 & 0.06 & 0.06 & 4.28 & $<0.05$ \\
\hline $\begin{array}{l}\text { B1dg. 1, Top of BTdg., At Top } \\
\text { of Process Vessel Previously } \\
\text { Used with Depleted Uranium }\end{array}$ & $3-2$ & 3.77 & 0.06 & 0.07 & 5.09 & $<0.05$ \\
\hline $\begin{array}{l}\text { Bldg. 1, Mezzanine, Dust } \\
\text { Sample Collected Inside Tear } \\
\text { on 01d Spray Dryer }\end{array}$ & $3-2$ & 3.67 & 0.06 & $<0.05$ & 2.93 & $<0.05$ \\
\hline $\begin{array}{l}\text { B1dg. 1, Central Portion of } \\
\text { Bidg., Near Blue Control Panel }\end{array}$ & $3-2$ & 0.7 & 0.8 & 0.5 & 1.2 & $<0.1$ \\
\hline $\begin{array}{l}\text { BIdg. 2, 2nd Floor, 15' From } \\
\text { Corner of B1dg.. Dust } \\
\text { Collected on Cross Structural } \\
\text { Support } 5^{\prime} \text { Off Floor }\end{array}$ & $3-2$ & 0.16 & 0.17 & $<0.05$ & 37.8 & 0.09 \\
\hline $\begin{array}{l}\text { Bldg. 2, 2nd Floor, } 15^{\prime} \text { From } \\
\text { Corner of Bldg.. Dust } \\
\text { Collected on Cross Structural } \\
\text { Support } 5^{\prime} \text { Off Floor }\end{array}$ & $3-2$ & 0.15 & 0.17 & 0.15 & 38.4 & $<0.05$ \\
\hline
\end{tabular}


TABLE X

Area Total Exposure Rate Readings

From A7pha, Beta, and Gamma Radiation

United Catalysts Inc.

South Plant

Louisville, Kentucky

HETA $82-358$

\begin{tabular}{|c|c|c|c|}
\hline Location & Date & Time & $\begin{array}{l}\text { Reading } \\
\text { (millirem } \\
\text { per hour) }\end{array}$ \\
\hline $\begin{array}{l}\text { Bldg. 2, 1st Floor Under 01d Carmen } \\
\text { Bagger, Used Meter at Waist Height }\end{array}$ & $3-2-83$ & 1130 & $0.5-1$ \\
\hline $\begin{array}{l}\text { B1dg. 2, lst Floor Under 01d Carmen } \\
\text { Bagger, Meter Used at Base of } \\
\text { Structural Beams }\end{array}$ & $3-2-83$ & 1137 & $0.5-1$ \\
\hline $\begin{array}{l}\text { Bidg. 1, Mezzanine Near Top of } \\
\text { B1dg. Above } 41 / 61 \text { Process Area. } \\
\text { On Top of Large Round Process } \\
\text { Vessel (no longer used). }\end{array}$ & $3-2-83$ & $\begin{array}{c}1200 \\
\text { (noon) }\end{array}$ & $1-3.5$ \\
\hline $\begin{array}{l}\text { BTdg. 1, Mezzanine } 41 / 61 \text { Area at } \\
\text { Spray Dryer on Side Near Calciner }\end{array}$ & $3-2-83$ & 1219 & $1-5$ \\
\hline $\begin{array}{l}\text { Bldg, } 1 \text {, Mezzanine } 41 / 61 \text { Area at } \\
\text { Smali Platform for Spray Dryer at } \\
\text { Spot Where Outer Cover of Spray } \\
\text { Dryer Was Torn (Tear is About at } \\
\text { Eye Leve I) }\end{array}$ & $3-2-83$ & 1221 & 10 \\
\hline $\begin{array}{l}\text { Bldg. 1, Mezzanine } 41 / 61 \text { Area at } \\
\text { Smali Platform for Spray Dryer at } \\
\text { Spot Where Outer Cover of Spray } \\
\text { Dryer Was Torn (Tear is About at } \\
\text { Eye Leve1) - Torn Cover was } \\
\text { Pulled out Sightly }\end{array}$ & $3-2-83$ & 1223 & $30-35$ \\
\hline
\end{tabular}


TABLE $\times$ (continued)

\begin{tabular}{|c|c|c|c|}
\hline Location & Date & Time & $\begin{array}{l}\text { Reading } \\
\text { (millirem } \\
\text { per hour) }\end{array}$ \\
\hline $\begin{array}{l}\text { Bldg. 1, Mezzanine } 41 / 61 \text { Area at } \\
\text { Sma11 Platform for Spray Dryer at } \\
\text { Spot Where Outer Lower of Spray } \\
\text { Dryer Was Torn (Tear is About at } \\
\text { Eye Level) - Torn Cover was } \\
\text { Pulled out further and some material } \\
\text { from inside had fallen out. }\end{array}$ & $3-2-83$ & 1236 & $5-10$ \\
\hline Bldg. 1, Mezzanine $41 / 61$ Calciner & $3-2-83$ & 1228 & 2 \\
\hline $\begin{array}{l}\text { Bldg. 1, } 41 / 61 \text { Area, Readings were } \\
\text { Taken at Mixing Tank, Filling } \\
\text { Station, Calciner, and Small } \\
\text { Tanks }\end{array}$ & $2-17-83$ & 1330 & $0.2-3$ \\
\hline Office Area (Background Sample) & $2-17-83$ & & 0.4 \\
\hline
\end{tabular}

Environmental Criteria (mR/hr): NRC $=2$ in any 1 hour (for unrestricted area). 


\section{TABLE XI}

Surface and Area Beta/Gamma Exposure Rate Readings

$$
\begin{gathered}
\text { United Catalysts, Inc. } \\
\text { South Plant } \\
\text { Louisville, Kentucky } \\
\text { HETA 82-358 } \\
\text { July 14, } 1983
\end{gathered}
$$

\begin{tabular}{|c|c|c|c|}
\hline Location & Time & Type & $\begin{array}{c}\text { Reading } \\
\text { (millirem/hr) }\end{array}$ \\
\hline $\begin{array}{l}\text { Bldg. 1. Mezzanine, } 41 / 61 \text { Spray Dryer } \\
\text { Inside Cover Tear 3.5' Above Platform Floor }\end{array}$ & 1330 & Surface & 4.5 \\
\hline $\begin{array}{l}\text { B1dg. 1. Mezzanine, } 41 / 61 \text { Area. On } \\
\text { Spray Dryer Platform. Inside Cover } \\
\text { Tear } 4.5^{\prime} \text { Above Platform Floor }\end{array}$ & 1345 & Surface & 6 \\
\hline $\begin{array}{l}\text { Bldg. 1. Mezzanine, } 41 / 61 \text { Area. Probe } \\
\text { At Piece of Spray Dryer Insulation } \\
\text { That had Fallen To The Platform Floor }\end{array}$ & 1350 & Surface & 3.5 \\
\hline $\begin{array}{l}\text { Bldg. 1. Mezzanine } 41 / 61 \text { Area, } 3^{\prime} \\
\text { Feet Above Platform Floor, Right Side } \\
\text { At Point Where Guard Rail Meets Round } \\
\text { Metal Spray Dryer Structure }\end{array}$ & 1400 & Surface & 8 \\
\hline Right Side of Spray Dryer Door & 1408 & Surface & 4 \\
\hline $\begin{array}{l}\text { Bottom of Spray Dryer Door. } 33^{\prime \prime} \text { Above } \\
\text { Platform Floor }\end{array}$ & 1430 & Surface & 6 \\
\hline $\begin{array}{l}\text { Probe At } 3^{\prime} \text { Above Platform Floor } \\
\text { (Waist High) And 6" From Spray Dryer }\end{array}$ & 1435 & Surface & 3.5 \\
\hline $\begin{array}{l}\text { Same As Above Except Probe 1' From } \\
\text { Spray Dryer }\end{array}$ & 1440 & Area & 2.5 \\
\hline $\begin{array}{l}\text { Same As Above Except Probe } 2^{\prime} \text { From Spray } \\
\text { Dryer Door }\end{array}$ & 1448 & Area & 2 \\
\hline
\end{tabular}




\begin{tabular}{|c|c|c|c|}
\hline Location & Time & Type & $\begin{array}{l}\text { Reading } \\
\text { (millirem/hr) }\end{array}$ \\
\hline $\begin{array}{l}\text { Probe Waist High And } 2^{\prime} \text { Feet From } \\
\text { Tear, Front End of P1atform, Probe } 5^{\prime} \\
\text { Above Platform Floor }\end{array}$ & 1505 & Area & 0.7 \\
\hline $\begin{array}{l}\text { On Mezzanine Floor, } 1 / 4 \text { Way } \\
\text { Around Spray Dryer (From Platform) } \\
\text { Probe } 5^{\prime} \text { Above Floor and } 2^{\prime} \text { From Spray Dryer }\end{array}$ & 1516 & Area & 0.4 \\
\hline $\begin{array}{l}\text { Same As Above Except Probe At Spray } \\
\text { Dryer Surface }\end{array}$ & 1516 & Surface & 0.9 \\
\hline $\begin{array}{l}\text { Other Side of Spray Dryer (Opposite Side } \\
\text { From Platform), Probe } 5 \text { ' Above Floor And } \\
\text { 2' From Spray Dryer }^{\prime}\end{array}$ & 1520 & Area & 0.1 \\
\hline $\begin{array}{l}\text { Same As Above Except Probe At Spray } \\
\text { Dryer Surface }\end{array}$ & 1520 & Surface & 0.1 \\
\hline $\begin{array}{l}3 / 4 \text { Way Around Spray Dryer (From } \\
\text { Platform). Probe } 5^{\prime} \text { Above Floor } \\
\text { And } 2^{\prime} \text { From Spray Dryer Surface }\end{array}$ & 1525 & Area & 0.2 \\
\hline $\begin{array}{l}\text { Same As Above Except Probe } \\
\text { At Spray Dryer }\end{array}$ & 1525 & Surface & 0.3 \\
\hline $\begin{array}{l}\text { Series of Measurements Obtained } \\
\text { On Top of Spray Dryer, Probe At } \\
\text { Surface In Inaccessible Areas } \\
\text { (Where Cleaning Was Difficult) }\end{array}$ & 1530 & Surface & $1.3-1.5$ \\
\hline $\begin{array}{l}\text { Series of Measurements } \\
\text { Same as Above Except Surface Measurement } \\
\text { Made where Cleaning Was Not As Difficult }\end{array}$ & 1530 & Surface & $>1$ \\
\hline $\begin{array}{l}\text { On Top of Spray Dryer, Probe Held Waist } \\
\text { High }\end{array}$ & 1545 & Area & 0.25 \\
\hline $\begin{array}{l}\text { On Top of Spray Dryer, Probe } 5 \text { Feet } \\
\text { Above Top of Spray Dryer }\end{array}$ & 1545 & Area & 0.15 \\
\hline $\begin{array}{l}\text { At Middle (On Both Sides) And At } \\
\text { Both Ends of Rotary Calciner }\end{array}$ & 1600 & Surface & $0.01-0.1$ \\
\hline
\end{tabular}


TABLE XI (continued)

\begin{tabular}{lccc}
\multicolumn{1}{c}{ Location } & Time & Type & $\begin{array}{c}\text { Reading } \\
\text { (millirem/hr) }\end{array}$ \\
\hline $\begin{array}{l}\text { Checked Edge Of Reactor Loading } \\
\text { Port At } 4 \text { locations }\end{array}$ & 1610 & Surface & $>0.1$ \\
\hline
\end{tabular}

Note: Alpha readings were also taken at most of the above locations. Al1 readings were the same as the background reading in the office (20 cpm).

Both alpha and beta/gamma meters were tested in the office using a check source before and after the meters were used.

Environmental criteria: NRC: $2.0 \mathrm{mR} / \mathrm{hr}$. for unrestricted area 


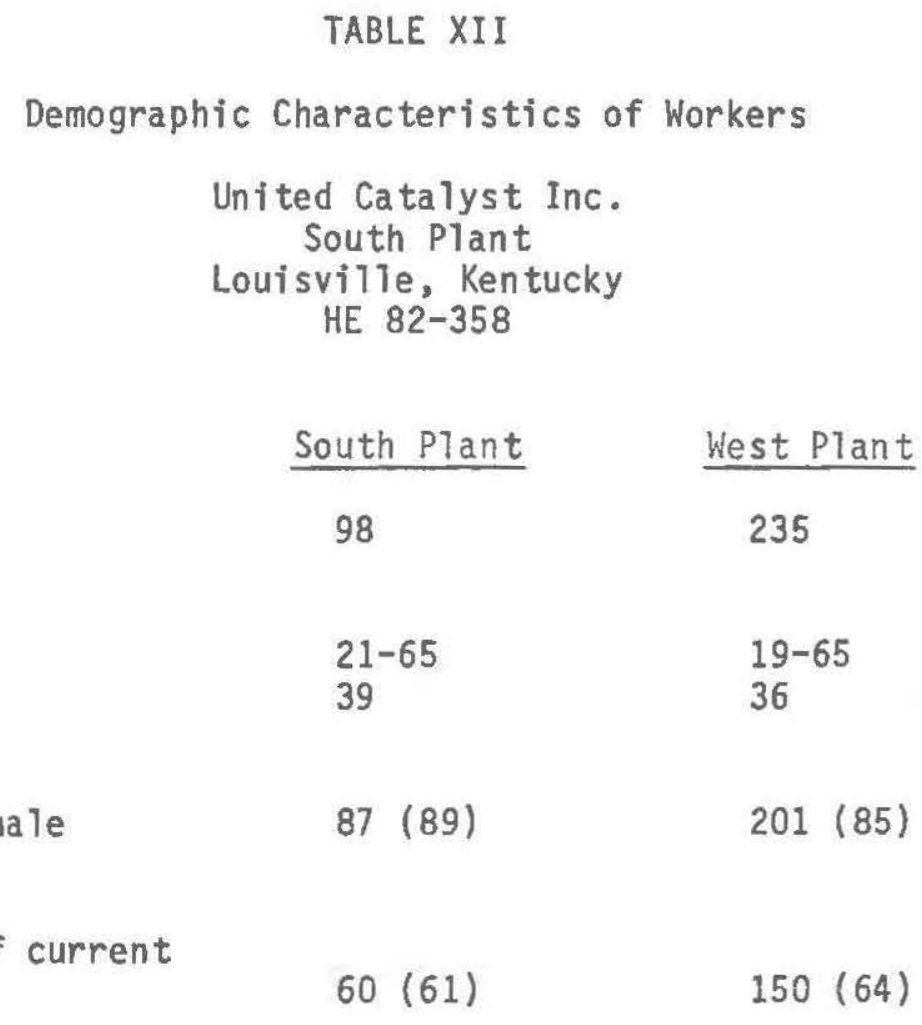




\section{TABLE XIII}

Numbers and percentages of workers Reporting Symptoms

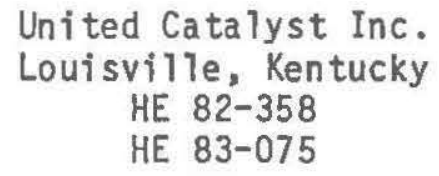

\begin{tabular}{|c|c|c|c|c|c|c|}
\hline \multirow[b]{2}{*}{ Symptom } & \multirow{2}{*}{$\frac{\text { Plant }(98}{\text { Number }}$} & \multirow{2}{*}{$\frac{\text { workers) }}{q}$} & \multicolumn{2}{|c|}{ West Plant (235 workers) } & \multicolumn{2}{|c|}{ Significance } \\
\hline & & & Number & $\%$ & Chi-Square & P-Value \\
\hline Cough & 48 & (49) & 106 & $(45)$ & 0.42 & $>0.5$ \\
\hline $\begin{array}{l}\text { Burning, } \\
\text { itchy, watery } \\
\text { eyes }\end{array}$ & 40 & (41) & 81 & (34) & 1.20 & $>0.25$ \\
\hline $\begin{array}{l}\text { Itchy burning } \\
\text { nose }\end{array}$ & 38 & $(39)$ & 97 & (41) & 0.18 & $>0.5$ \\
\hline Nasal sores & 34 & (35) & 47 & (20) & 8.11 & $<0.01$ \\
\hline $\begin{array}{l}\text { Shortness of } \\
\text { breath }\end{array}$ & 33 & (34) & 70 & $(30)$ & 0.49 & $>0.25$ \\
\hline $\begin{array}{l}\text { Chest tight- } \\
\text { ness }\end{array}$ & 28 & (29) & 61 & $(26)$ & 0.24 & $>0.5$ \\
\hline Skin rash & 26 & $(27)$ & 92 & (39) & 4.81 & $<0.05$ \\
\hline Wheezing & 24 & $(25)$ & 60 & $(26)$ & 0.04 & $>0.75$ \\
\hline $\begin{array}{l}\text { One or more } \\
\text { symptoms }\end{array}$ & 68 & $(70)$ & 169 & $(72)$ & 0.22 & $>0.5$ \\
\hline
\end{tabular}


TABLE XIV

Locations of Skin Rashes

United Catalyst Inc.

Louisville, Kentucky

HE 82-358

HE 83-075

\begin{tabular}{|c|c|c|c|c|c|c|}
\hline \multirow[b]{2}{*}{ Location } & \multicolumn{2}{|c|}{ h Plant (26 workers) } & \multicolumn{2}{|c|}{ West Plant ( 92 workers) } & \multicolumn{2}{|c|}{ Significance } \\
\hline & Number & $\%$ & Number & $\%$ & Chi-Square & $P-V a l u e$ \\
\hline Hands & 26 & $(100)$ & 71 & (77) & 7.16 & $<0.1$ \\
\hline $\begin{array}{l}\text { Face and } \\
\text { neck }\end{array}$ & 20 & $(80)$ & 50 & $(54)$ & 4.32 & $<0.05$ \\
\hline Arms & 19 & (73) & 42 & $(46)$ & 6.19 & $<0.025$ \\
\hline $\begin{array}{l}\text { Chest, back } \\
\text { and abdomen }\end{array}$ & 15 & (58) & 36 & (39) & 2.90 & $>0.05$ \\
\hline Legs & 13 & $(50)$ & 33 & (36) & 1.70 & $>0.1$ \\
\hline $\begin{array}{l}\text { Neck and } \\
\text { underarms }\end{array}$ & 9 & $(35)$ & 30 & (33) & 0.04 & $>0.75$ \\
\hline Feet & 8 & (31) & 24 & (26) & 0.22 & $>0.5$ \\
\hline
\end{tabular}




\section{TABLE XV}

Characteristics of skin rashes

United Catalyst Inc.

Louisville, Kentucky

HE 82-358

HE 83-075

\begin{tabular}{|c|c|c|c|c|c|c|}
\hline \multirow[b]{2}{*}{ Location } & \multicolumn{2}{|c|}{ Plant (26 workers) } & \multicolumn{2}{|c|}{ West Plant ( 92 workers) } & \multicolumn{2}{|c|}{ Significance } \\
\hline & Number & $\%$ & Number & $\%$ & Chi-Square & $P$-Value \\
\hline Red itchy skin & 20 & $(77)$ & 57 & (61) & 1.93 & $>0.1$ \\
\hline Dry cracked skin & 19 & (73) & 70 & $(76)$ & 0.1 & $>0.75$ \\
\hline $\begin{array}{l}\text { Red skin and } \\
\text { blisters }\end{array}$ & 11 & (43) & 17 & (18) & 6.26 & $<0.025$ \\
\hline $\begin{array}{l}\text { Patches of } \\
\text { thickened skin }\end{array}$ & 6 & (23) & 15 & (16) & 0.64 & $>0.25$ \\
\hline Color change & 6 & $(23)$ & 15 & (16) & 0.64 & $>0.25$ \\
\hline $\begin{array}{l}\text { Frequent skin } \\
\text { sores }\end{array}$ & 4 & $(15)$ & 8 & (9) & - & $0.30 *$ \\
\hline $\begin{array}{l}\text { Cracked deformed } \\
\text { fingernails }\end{array}$ & 3 & $(12)$ & 20 & $(22)$ & 1.34 & $>0.1$ \\
\hline
\end{tabular}

* Fisher's Exact Test, 2-Tailed 
TABLE XVI

Number and Percentage of Workers with Respiratory Symptoms

United Catalyst Inc.

Louisville, Kentucky

HETA $82-358$

HETA 83-075

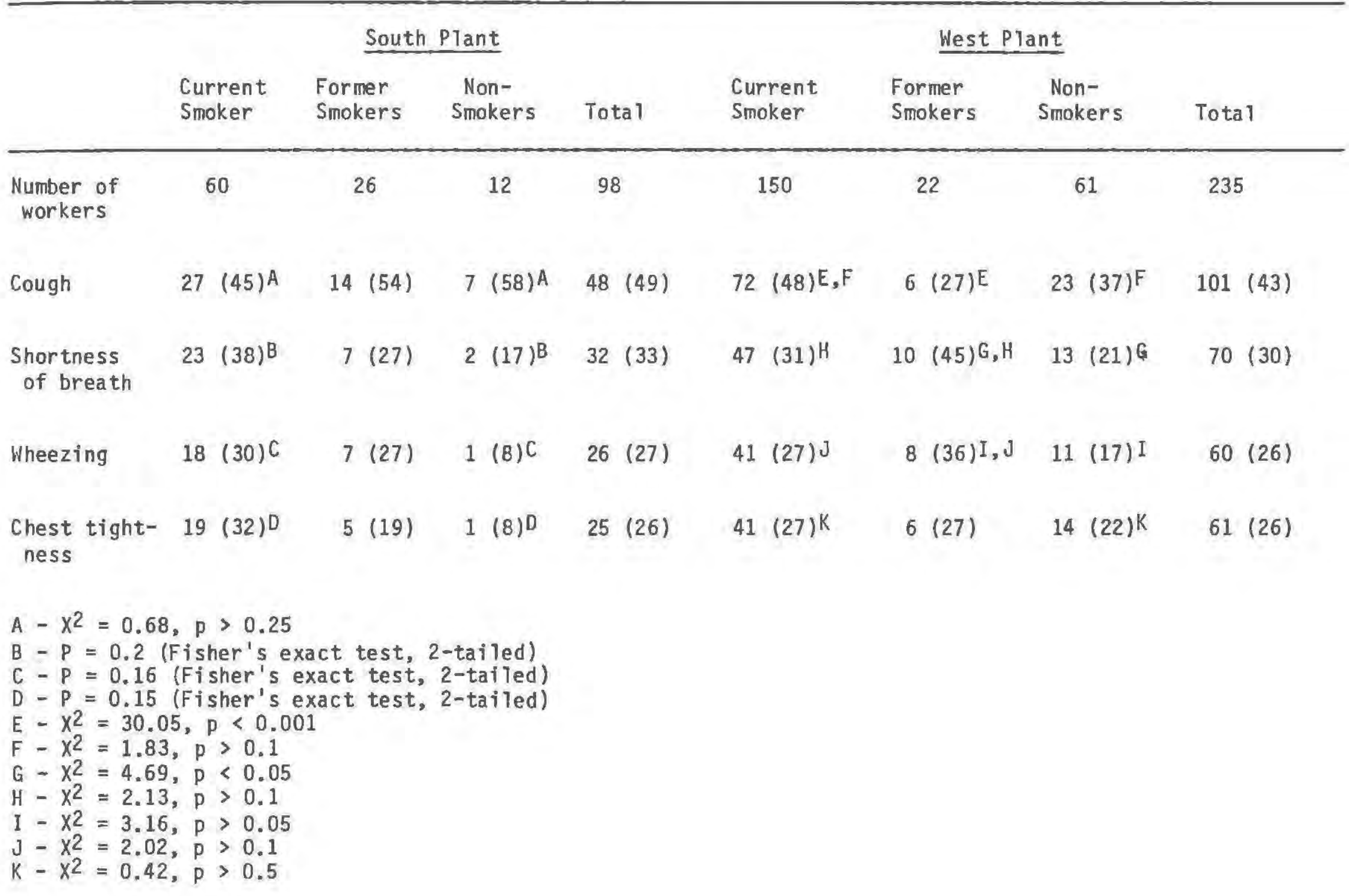


TABLE XYII

Workers Reporting Symptoms In High. Medium and Low Exposure Groups

United Catalyst Inc.

Loutsville, Kentucky

$$
\text { HE } 82-358
$$

HE $83-075$

\begin{tabular}{|c|c|c|c|c|c|c|c|c|c|c|}
\hline \multirow[b]{3}{*}{ Symptoms } & \multirow[b]{2}{*}{ High 188} & \multicolumn{3}{|c|}{ Exposure Groups* } & \multirow{2}{*}{ Low 149} & \multirow{2}{*}{ workers) } & \multicolumn{3}{|c|}{ Signiflcance } & \multirow[b]{2}{*}{ Low Exposure } \\
\hline & & workers) & Hedium 192 & workers) & & & High -vs- Low & Exposure & Medlum -vs- & \\
\hline & Number & 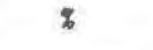 & Number & 8 & Number & $\bar{z}$ & Chi-Square & P-Yalue & Cht-5quare & P-Value \\
\hline $\begin{array}{l}\text { Itchy burning } \\
\text { nose }\end{array}$ & 48 & (55) & $4 B$ & (52) & 8 & (16) & 18.94 & $<0.001$ & 17.27 & $<0.001$ \\
\hline Cough & 48 & $(55)$ & 49 & (53) & 10 & $(20)$ & 15.02 & $<0.001$ & 14.17 & $<0.001$ \\
\hline $\begin{array}{l}\text { Burning Itchy } \\
\text { watery eyes }\end{array}$ & 37 & $(42)$ & 47 & (51) & 7 & (14) & 11.14 & $<0.001$ & 18.42 & $<0.001$ \\
\hline Skin rash & 34 & (39) & 34 & $(39)$ & 8 & (16) & 7.37 & $<0.01$ & 6.51 & $<0.025$ \\
\hline $\begin{array}{l}\text { Shortness of } \\
\text { breath }\end{array}$ & 33 & (38) & 33 & (38) & 5 & (10) & 11.70 & 0.001 & 10.70 & $<0.01$ \\
\hline Wheezing & 26 & (30) & 28 & $(30)$ & 5 & $(10)$ & 6.73 & $<0.01$ & 7.30 & $<0.01$ \\
\hline $\begin{array}{l}\text { Chest tight- } \\
\text { ness }\end{array}$ & 24 & (27) & 32 & (35) & 5 & (10) & 5.50 & $<0.025$ & 9.98 & $<0,01$ \\
\hline Nasal sores & 23 & (26) & 19 & (21) & 2 & (14) & 10.26 & $<0.001$ & 6.93 & $<0.01$ \\
\hline None & $B$ & (9) & 19 & (21) & 33 & $(67)$ & 50.94 & $<0.001$ & 29.02 & $<0.001$ \\
\hline
\end{tabular}

* Exposure groups are defined in the tert 
Summary of Airborne Sampling Results

Personal Full-Shift Samples

United Catalyst Inc. - South Plant

Louisville, Kentucky

HETA $82-358$

\begin{tabular}{|c|c|c|c|c|c|}
\hline Material & $\begin{array}{l}\text { Lowest } \\
\text { Evaluation } \\
\text { Criterion }\end{array}$ & $\begin{array}{l}\text { Number of } \\
\text { Samples }\end{array}$ & $\begin{array}{l}\text { Exposure } \\
\text { Range }\end{array}$ & $\begin{array}{l}\quad \text { Number }(\%) \text { of } \\
\text { Samples Exceeding at } \\
\text { Least One Criterion }\end{array}$ & $\begin{array}{l}\text { Average Exposure } \\
\text { (Standard Deviation) }\end{array}$ \\
\hline Nickel & $15 \mathrm{ug} / \mathrm{m}^{3}-\mathrm{NIOSH}$ & 33 & $23-680 \mathrm{ug} / \mathrm{m}^{3}$ & $33(100 \%)$ & $126(159)$ \\
\hline Copper & $1000 \mathrm{ug} / \mathrm{m}^{3}-0$ SHA $/$ ACGIH & 12 & $12-674 \mathrm{ug} / \mathrm{m}^{3}$ & $0(-)$ & $110(183)$ \\
\hline $\begin{array}{l}\text { Chromi um- } \\
\text { Tota } 7\end{array}$ & $500 \mathrm{ug} / \mathrm{m}^{3}-O S H A / A C G I H$ & 33 & LLD $-37 \mathrm{ug} / \mathrm{m}^{3}$ & $0(-)$ & $9.2(7.1)$ \\
\hline Lead & $50 \mathrm{ug} / \mathrm{m}^{3}-0 S H A$ & 12 & LLD-7 $\mathrm{ug} / \mathrm{m}^{3}$ & $0(-)$ & $1.7(*)$ \\
\hline Coba1t & $100 \mathrm{ug} / \mathrm{m}^{3}-0$ SHA/ACG IH & 12 & $3-7 \mathrm{ug} / \mathrm{m}^{3}$ & $0(-)$ & $4.8(1.2)$ \\
\hline Anmonia & $18 \mathrm{mg} / \mathrm{m}^{3}-\mathrm{ACG} I H$ & 2 & $1.67-2.89 \mathrm{mg} / \mathrm{m}^{3}$ & $0(-)$ & $2.3(0.86)$ \\
\hline $\begin{array}{l}\text { Sulfuric } \\
\text { Acid }\end{array}$ & $1 \mathrm{mg} / \mathrm{m}^{3}-\mathrm{NIOSH} /$ OSHA/ACGIH & 3 & A11 LLD & $0(-)$ & $-(*)$ \\
\hline $\begin{array}{l}\text { Respirable } \\
\text { Particulates }\end{array}$ & $5 \mathrm{mg} / \mathrm{m}^{3}-\mathrm{OSHA} / \mathrm{ACGIH}$ & 4 & $0.19-0.48 \mathrm{mg} / \mathrm{m}^{3}$ & $0(-)$ & $0.39(0.1)$ \\
\hline Quartz & $0.05 \mathrm{mg} / \mathrm{m}^{3}-\mathrm{NIOSH}$ & 4 & A11 LLD & $0(-)$ & $-(*)$ \\
\hline
\end{tabular}

- = Not applicable

* = Standard deviation not analyzed due to high percentage of non-detected values

LLD = Below laboratory limit of detection.

Note: For calculating $\bar{x}$ and S.D. for samples with LLD values used midpoint between 0.0 and highest concentration possible, which was determined using laboratory limit of detection - volume. 